\title{
Pretreatment of citrus by-products affects polyphenol recovery: a review
}

Konstantinos Papoutsis

Quan V. Vuong

John B. Golding

Joaquín $\mathrm{H}$. Hasperué

Penta Pristijono

Michael C. Bowyer

Christopher J. Scarlett

Costas E. Stathopoulos

This is an Accepted Manuscript of an article published by

Taylor \& Francis in Food Reviews International on 26th February 2018, available online:

http://wwww.tandfonline.com/10.1080/87559129.2018.1438471 
Pretreatment of citrus by-products affects polyphenol recovery: A Review Konstantinos Papoutsis $^{1}$, Quan V. Vuong ${ }^{1}$, John B. Golding ${ }^{1,2}$, Joaquín H. Hasperué ${ }^{4}$, Penta Pristijono ${ }^{1}$, Michael C. Bowyer ${ }^{1}$, Christopher J. Scarlett ${ }^{1}$, Costas E. Stathopoulos ${ }^{3}$

${ }^{1}$ School of Environmental and Life Sciences, The University of Newcastle PO Box 127 Ourimbah, NSW 2258, Australia

${ }^{2}$ NSW Department of Primary Industries, Locked Bag 26 Gosford, NSW 2250, Australia

${ }^{3}$ Division of Food and Drink School of Science, Engineering and Technology University of Abertay Dundee DD1 1HG UK

${ }^{4}$ Center for Research and Development in Food Cryotechnology (CIDCA, National University of La Plata-CONICET), Calle 47 y 116, La Plata (1900), Buenos Aires, Argentina

*Corresponding author: $\mathrm{PhD}$ Candidate, Konstantinos Papoutsis; e-mail addresses: Konstantinos.Papoutsis@uon.edu.au; Nutrition Food \& Health Research Group, School of Environmental and Life Sciences, University of Newcastle, Brush Rd, Ourimbah, NSW 2258, Australia.

Running title: Pre-treatment of citrus by-products 


\begin{abstract}
A large amount of citrus waste is generated annually. This waste is of great economic worth, since it contains high levels of polyphenols, which have attracted scientific interest due to their potent antimicrobial and antiradical activities. Pre-treatment is a crucial step that precedes the extraction process and influences the yields and quality of polyphenols. This review emphasizes the effect of different drying processes, such as freeze drying, hot-air drying, vacuum drying, infrared drying, and high-speed drying, on the polyphenol retention in citrus by-products. Further treatments of the dried citrus by-products for assisting the liberation of bound polyphenols are also provided and comprehensively discussed.
\end{abstract}

KEYWORDS: Citrus pomace; drying techniques; polyphenol liberation; treatment of dried pomace; valorization; lyophilisation.

\title{
Abbreviations:
}

TPC: Total phenolic content.

TF: Total flavonoid content.

PPO: Polyphenol oxidase.

POD: Peroxidase.

CAE: Caffeic acid equivalents.

d.e: Dry extract.

d.w.: Dry weight.

kGy: kiloGray.

kJ: kilojoule.

EBI: Electron-beam irradiation.

UV: Ultraviolet. 


\section{Introduction}

Citrus is one of the most economically important crops with a worldwide production exceeding $121 \times 10^{6}$ tons [1]. Citrus fruits are usually processed by the industry for the production of juice $[2,3]$. During juice production, a large amount of citrus by-products are generated, mainly consisting of peel and seed residues. This material has recently attracted scientific interest since several studies have pointed out that citrus by-product (also known as pomace) is a good source of polyphenols, which have been linked to antimicrobial [4], antifungal [5], anticancer [6] and antioxidant activities [7, 8]. It is known that polyphenols can be degraded by exposure to light, oxygen and high temperature $[9,10]$. Therefore, citrus byproducts should be appropriately handled for retaining high polyphenol content.

Phenolic compounds are the most abundant secondary metabolites synthesized by plants as a response to external stresses, such as UV irradiation, wounding, pathogen attack or during plant maturation $[11,12]$. Flavonoids and phenolic acids are the main classes of polyphenols found in citrus by-products [13]. More than 60 flavonoid compounds have been identified in citrus and sub-classified as flavanones, flavones, and flavonols [14] (Table 1). Citrus flavonoids are present in glycoside (C- or O-glycosides) or aglycone forms, with the glycoside being the dominant form [13]. Phenolic acids are phenols containing one carboxylic acid and divided into hydroxycinnamic and hydroxybenzoic acids [15]. Phenolic acids in plant tissues are present in free and bound forms, with the free forms being more active than the bound ones [16]. Table 2 illustrates the phenolic acid content of different citrus species peels.

Citrus by-products are exposed to undesirable environmental conditions (oxygen, high temperatures), which might lead to polyphenol degradation. Therefore, for obtaining high polyphenol extraction yields, apart from the selection of the most efficient extraction technique, the preservation of polyphenols on the citrus by-product should be considered. Citrus byproducts are prone to degradation and spoilage due to their high moisture content. Usually, 
drying precedes extraction for moisture removal and polyphenol preservation. However, undesirable drying conditions may cause degradation of polyphenols, leading to lower extraction yields. A number of drying techniques have been employed for the dehydration of citrus by-products, such as freeze drying, hot-air drying, vacuum drying, sun drying, infrared drying, far-infrared drying, and high-speed drying, demanding different energy requirements and exerting various effects on the different classes of polyphenols [9, 10, 17-19]. For instance, drying at high temperatures may result in the liberation of the bound polyphenols facilitating greater recovery. However, at high temperatures, some polyphenols might be oxidized and converted to others leading to lower extraction yields [20]. When the drying process is conducted under sunlight, a reduction in the retention of polyphenols may occur due to photooxidation. The merits and demerits of each drying technique are summarized in Table 3 and are comprehensively discussed in the following sections [21].

As previously mentioned, polyphenols in citrus by-products are often linked to cell wall polymers. Recent studies have shown that the liberation of bound polyphenols from citrus byproducts can be achieved by applying further treatments, such as heat (conventional or microwave ovens) or irradiation (electron-beam and UV-C irradiations) to the dried materials $[16,22-26]$. During the heat treatment, the ester and glucoside bonds can be broken down resulting in the liberation of the bound polyphenols. At the same time, heat may lead to polyphenol transformation explaining why the content of some phenolic compounds increases, while the content of others decreases [27]. In case of irradiations, the exact mechanism has not yet been elucidated, however, it could be hypothesized, that the higher polyphenol yields might be due to the breakdown of the bound polyphenols caused by heating effects due to the transfer of energy of many photons [28].

To date, several reviews have been published presenting and discussing the different extraction techniques that have been applied on citrus by-products for the recovery of 
polyphenols [29-31]. However, to the best of our knowledge, there is no review discussing the effect of different drying conditions on the recovery of polyphenols from citrus by-products. Therefore, this review aims to provide information about the effect of different drying techniques and conditions on the polyphenol recovery from citrus by-products. Moreover, additional steps that are used to enhance the extraction procedure for liberating and obtaining high quality polyphenol extracts are comprehensively discussed.

\section{Impact of drying techniques on citrus by-product polyphenols}

Drying is a crucial but not mandatory step that precedes extraction process (Fig. 1). Citrus by-products contain a significant amount of moisture which promotes microbial spoilage and chemical alterations [32-34]. Even though citrus by-products could be stored in a freezer as fresh, dehydration is recommended for several reasons. After dehydration, i) the activity of enzymes that are responsible for the degradation of polyphenols, such as polyphenol oxidase (PPO) or peroxidase (POD), is significantly reduced, therefore higher polyphenol yields are obtained [33, 35] (Fig. 2), ii) citrus wastes are not vulnerable to pathogen spoilage [36], and iii) the packaging volume is significantly lower, hence less storage place is required and the transportation cost is reduced.

A number of studies have indicated that undesirable drying conditions may negatively affect the extraction yields of polyphenols from citrus by-products [9, 10, 37]. Several parameters should be considered for the selection of the drying technique, including energy consumption, retention of polyphenols and antioxidants in the dried material, as well as its effect on the physical properties of the dried product. The application and effects of different techniques on the retention of polyphenols are discussed in the following sections. Table 4 illustrates the studies that have been conducted to evaluate the effect of different drying techniques on the retention of polyphenols in citrus by-products. 


\subsection{Freeze drying (lyophilization)}

Freeze drying or lyophilization is a drying technique operating at low temperature and under vacuum $[35,38]$. Freeze drying has been widely used for drying citrus by-products [7, $39,40]$ since, unlike other techniques, it prevents the discoloration of the dried material, it prohibits the degradation of heat or oxygen sensitive bioactive compounds and it effectively removes the moisture from the materials. Hence, it promotes the storability of the product by minimizing enzyme and pathogen activity [29, 41]. However, it requires longer drying times (varying from 12 to $72 \mathrm{~h}$ ) and higher energy consumption than other drying techniques $[9,10$, $42,43]$.

According to the literature, freeze drying has different effects on the retention and recovery of different classes of polyphenols being found in citrus by-products. For instance, freeze drying could be effectively applied on citrus by-products for the retention of neoeriocitrin, neodiosmin, hesperidin, nobiletin, caffeic acid, and neohesperidin $[9,10,44,45]$. However, some contradictory results related to the effect of freeze drying on the retention of TPC, antioxidants and phenolic acids on the dried citrus by-products have been noticed $[9,10$, 39, 45]. Sun, Shen, Liu and Ye [9] indicated that freeze drying is a more effective technique for maintaining TPC, phenolic acids and antioxidants in the peels of four citrus species comparing with hot-air drying $\left(60^{\circ} \mathrm{C}\right)$ and sun drying. Similar results were reported by Assefa and Keum [42] who found higher retention of TPC and flavonoids in the citrus peels dried by freeze drying than those dried by hot-air drying $\left(50^{\circ} \mathrm{C}\right)$, and those dried at ambient temperature. On the other hand, Lou, Lin, Hsu, Chiu and Ho [45] indicated higher recovery of TPC ad flavonoids from the immature calamondin peels after drying at $150{ }^{\circ} \mathrm{C}$ compared to the freeze dried ones. Chen, Yang and Liu [39] found that orange peels dried at temperatures higher than $70{ }^{\circ} \mathrm{C}$ had higher TPC compared to those dried by freeze drying. The different results could be attributed to the different drying operating conditions used in each study. In general, freeze 
drying is an efficient drying technique for the retention of citrus by-product polyphenols when it is compared with hot-air drying being conducted at relatively lower temperatures $\left(<60{ }^{\circ} \mathrm{C}\right)$ [39]. As the hot-air drying temperature decreases the required drying time increases, resulting in the degradation of some phenolic compounds due to enzymatic oxidation. On the other hand, hot-air drying at high temperatures $\left(>70^{\circ} \mathrm{C}\right)$ is more efficient than the freeze drying technique $[10,39]$. High temperatures may result in the denaturation of the enzymes being implicated in the oxidation of phenolic compounds and promote the liberation of the bound polyphenols [9, 45]. Therefore, greater TPC yields are obtained compared to the freeze drying.

\subsection{Hot-air drying}

During hot-air drying, heat is transferred to the material by convection and dehydration takes place. In general, hot-air drying requires shorter drying times and energy consumption than freeze drying [10]. The effect of hot-air drying at different operating conditions on the recovery of total and individual polyphenols has been extensively studied and compared with other drying techniques $[10,37,39,43,44,46]$. Previous studies have shown that hot-air drying could be effectively applied to citrus by-products for high recovery of polyphenols and antioxidants $[9,10,46]$. However, three parameters should be considered when hot-air drying is applied, namely, i) drying temperature, ii) drying time, and iii) air velocity, since undesirable hot-air drying conditions may lead to degradation and significant loss of polyphenols. During hot-air drying polyphenol enzymatic and non-enzymatic degradation may take place [20]. Hotair drying results in the disruption of cell walls and the liberation of bound polyphenols. At the same time, oxidative and hydrolytic enzymes are released which can degrade the liberated phenolic compounds. As the applied temperature increases the released enzymes are inactivated. At high temperatures a non-enzymatic polyphenol degradation/conversion takes 
place and a discoloration of the dried material occurs [10,39, 45-48], which has been attributed to the formation of Maillard reaction products [49].

Lou, Lin, Hsu, Chiu and Ho [45] indicated that the TPC, phenolic acid and flavonoid content of immature calamondin peels dried by hot air at $150{ }^{\circ} \mathrm{C}$ was significantly higher than those dried at lower temperatures or freeze dried. However, at these conditions, the recovery of some individual compounds ( $3^{\prime}, 5^{\prime}$-Di-C- $\beta$-glucopyranosylphloretin, and hesperidin) was significantly lower (90 and $290 \mathrm{mg} / 100 \mathrm{~g}$ d.e., respectively) compared to the peels dried by freeze drying (4322 and $430 \mathrm{mg} / 100 \mathrm{~g}$ d.e., respectively). During hot-air drying at high temperatures some phenolic compounds might be degraded and converted into other products since high temperatures results in the polyphenol deglycosylation [50]. Interestingly, the authors found varying effects on the retention of individual phenolic acids. For instance, ferulic acid, $p$-coumaric acid, and gallic acid were not detected in the extracts of the freeze dried peels but were found in the extracts of the peels dried by hot air, while the opposite was found for the caffeic acid [45]. The higher ferulic acid, p-coumaric acid, and gallic acid yields obtained from the hot-air dried peels could be attributed to the thermal destruction of cell walls, to the liberation of the bound phenolic acids, as well as to the conversion of some phenolic acids to others due to the heat treatment [50]. The reduced caffeic acid yields could be attributed to the oxidation and transformation of caffeic to ferulic acid. Ferulic acid is biosynthesized from the caffeic acid by O-methylation, a reaction which increases as the temperature increases [51, 52]. Similarly, Papoutsis, Pristijono, Golding, Stathopoulos, Bowyer, Scarlett and Vuong [10] found that hot-air drying conditions had varying effects on the recovery of phenolic acids from lemon by-products. Higher gallic acid content was obtained from the lemon by-products dried at $110{ }^{\circ} \mathrm{C}(8.71 \mu \mathrm{g} / \mathrm{mL})$ than those dried at 70 and $90{ }^{\circ} \mathrm{C}(1.10$ and $4.69 \mu \mathrm{g} / \mathrm{mL}$, respectively $)$, while $p$-coumaric acid content was higher in the extracts of the by-products dried at 90 and 70 ${ }^{\circ} \mathrm{C}\left(1.03\right.$ and $0.99 \mu \mathrm{g} / \mathrm{mL}$, respectively), than those dried at $110{ }^{\circ} \mathrm{C}(0.71 \mu \mathrm{g} / \mathrm{mL})$. 
Ghanem Romdhane, Bonazzi, Kechaou and Mihoubi [37] investigated the effect of different hot air temperatures $\left(40-60{ }^{\circ} \mathrm{C}\right)$ on the degradation kinetics of TPC and flavonoids of lemon peels. In the range of $40-60{ }^{\circ} \mathrm{C}$, a significant reduction in the TPC and flavonoid contents were observed, with the temperature of $40{ }^{\circ} \mathrm{C}$ resulting in the highest reduction of TPC and flavonoid contents ( 72 and 20\%, respectively). The degradation kinetics of both compounds were fitted to a first-order equation. These findings revealed that phenolic compounds in citrus by-products are susceptible to degradation when the materials are dried at low temperatures for a long time, thus, drying temperature exhibits an important influence on the degradation rates of polyphenols. During citrus by-product drying at low temperatures, a rapid polyphenol degradation may occur due to PPO activity during the first hour of the process [53]. Ghanem Romdhane, Djendoubi, Bonazzi, Kechaou and Boudhrioua Mihoubi [54] investigated the kinetics of lemon peel polyphenol degradation during osmo-dehydration (50$70 \% \mathrm{w} / \mathrm{w})$ at different temperatures $\left(30-50^{\circ} \mathrm{C}\right)$ followed by hot-air drying (at 40 and $60{ }^{\circ} \mathrm{C}$ ). A significant decrease (70-80\%) in the TPC of the osmo-dehydrated lemon peels was observed with increasing sucrose concentration (from 50 to $70 \% \mathrm{w} / \mathrm{w}$ ) and sucrose solution temperature (from 30 to $50{ }^{\circ} \mathrm{C}$ ). However, following osmo-dehydration, drying citrus by-products at 40 or $60{ }^{\circ} \mathrm{C}$, had no significant effect on the TPC. The polyphenol loss took place during osmodehydration was attributed to the osmotic driving force which promotes the migration of soluble phenolic compounds from the peels to the osmotic solution [54]. Future studies should be conducted in order to investigate the exact mechanism being involved in the retention of polyphenols during drying after osmo-dehydration.

Hot-air drying being a lower energy consumption method than freeze drying, could be effectively applied for drying citrus by-products. However, the drying conditions should be carefully selected for avoiding polyphenol degradation, since different drying temperatures show varying effects on the different classes of citrus by-product polyphenols. In conclusion, 
hot-air drying at high temperatures may promote the recovery of phenolic compounds from citrus by-products, while hot-air drying at low temperatures might have adverse effects.

\subsection{Sun drying}

Sun drying is a low-cost drying technique since it does not require any expensive instrument installation; however, it is dependent on various environmental parameters, including relative humidity, temperature, air velocity, and solar intensity among others. During sun drying, microbial contamination of the citrus by-products may occur contributing to the loss of the dried material quality. Moreover, sun drying requires prolonged drying periods, which may negatively affect the retention of polyphenols in the dried material $[9,34]$. Sun, Shen, Liu and Ye [9] mentioned that the flavonoid and phenolic acid contents of different immature citrus species dried by sun drying (for 3 days) were significantly lower than those dried by freeze drying (for $12 \mathrm{~h}$ ) or hot-air drying at $60{ }^{\circ} \mathrm{C}$ (for $10 \mathrm{~h}$ ). Authors attributed this results to PPO activity which might be higher in the samples dried under environmental conditions, leading to polyphenol degradation. Even though sun drying is a low-cost drying technique, it requires extended drying times that might negatively affect the concentration of citrus by-product polyphenols. The reduced polyphenol retention in the sun dried citrus byproducts could be attributed to the polyphenol enzymatic oxidation (PPO) due to the presence of oxygen, as well as to the photo-oxidation of some phenolic compounds. When citrus byproducts are exposed to the sun, the UV irradiation may induce the formation of free radicals which may be scavenged by the phenolic compounds, resulting in polyphenol oxidation [21].

\subsection{Vacuum drying}

Vacuum drying has been applied for drying various fruits and vegetables $[55,56]$. However, it has been rarely used for the dehydration of citrus by-products. During vacuum 
drying, the moisture removal from the raw material takes place under low pressure in the absence of oxygen, preventing the enzymatic oxidation of phenolics [56] (Fig. 2). A recent study compared the effect of vacuum drying operating at different conditions with hot-air drying and freeze drying on the retention of polyphenols of lemon by-products [10]. Vacuum drying temperature significantly affected the recovery of different classes of lemon by-product polyphenols [10]. During vacuum drying, the heat energy may cleave the polyphenols being linked to the cell wall polymers, facilitating higher recovery of the free forms, however, temperatures higher than the optimum may result in the degradation of the heat sensitive phenolic compounds $[16,23]$. For instance, high rutin and $p$-coumaric acid extraction yields were achieved by drying lemon by-products with vacuum drying at $70{ }^{\circ} \mathrm{C}(137.04$ and 1.69 $\mu \mathrm{g} / \mathrm{mL}$, respectively), which were significantly higher than those obtained by freeze drying (119.29 and $1.10 \mu \mathrm{g} / \mathrm{mL}$, respectively) or hot-air drying at $70{ }^{\circ} \mathrm{C}(107.31$ and $0.99 \mu \mathrm{g} / \mathrm{mL}$, respectively). These results indicate that during the thermal processing of citrus by-products, some bound phenolic compounds might be liberated. However, drying temperatures higher that the optimum might lead to polyphenol degradation due to cleavage of covalent bonds [57]. According to the previous results, comparing vacuum drying with hot-air drying, it could be concluded that during hot-air drying some polyphenols might be oxidized due to material exposure to oxygen. The advantages of vacuum drying over other drying techniques include: i) less energy consumption compared to freeze drying, ii) lower processing temperatures compared to hot-air drying, therefore less polyphenol degradation due to heat, and iii) prevention of polyphenol enzymatic degradation, since it takes place in oxygen absence [55] (Fig. 2). However, during vacuum drying at high temperatures, a discoloration of the dried material may occur [10].

\subsection{Microwave drying techniques}


Microwaves have been used in several food procedures including pasteurization and cooking, among others since they result in substantially reduced processing times [58]. During microwave drying, the microwave power is absorbed by the peels and leads to internal water heating and moisture evaporation. During this process, the solubility of the pectic material of the middle lamellae increases, facilitating cell wall rupture [59]. The microwave processing time decreases as the microwave power increases and depends on the citrus species [59]. Citrus species with thicker peels require shorter microwave drying times [59]. Recently, the effect of microwave drying on the retention of citrus by-product polyphenols was investigated $[42,59$, 60]. Microwave drying may have varying effects on the retention of TPC of the different citrus species. For instance, microwave drying negatively affected the retention of TPC in mandarin and lemon peels, while it enhanced the TPC recovery from orange peels [59]. Kammoun Bejar, Kechaou and Boudhrioua Mihoubi [60] investigated the effect of different microwave drying conditions (power ranging between 100-850W) on the retention of TPC of orange peels. The retention of TPC increased as the microwave power increased to an optimum level and then declined. The power of $450 \mathrm{~W}$ found to be optimum for the recovery of TPC $(1.88 \mathrm{~g} \mathrm{CAE} / 100 \mathrm{~g}$ d.w.). Higher microwave powers negatively affected the recovery of TPC. This effect could be due to the thermal degradation of some phenols because of the heat developed during the microwave process. Microwave powers lower than $450 \mathrm{~W}$ reported being unfavorable for the recovery of TPC probably due to the oxidation of some of the phenolic compounds due to oxygen exposure for a long time [60]. Due to its rapidity, microwave drying could be employed for drying citrus by-products [58]; however, studies investigating and determining the effect of different microwave operating conditions on the retention of individual phenolic compounds in different citrus species should be conducted.

\subsection{High-speed drying}


Senevirathne, Jeon, Ha and Kim [19] used high-speed drying, which is a rapid and economical technique for drying citrus by-products. Fig. 3 illustrates the diagram of a highspeed drier. During high-speed drying, the plant material is placed into the sample compartment of the system. The loaded material is conducted upwards to the heat transmitting wall by the rotating cyclone fin and it is held against the heating wall in a thin film by centrifugal force. The wall is heated by the steam supplied by the steam generator. The waste steam from the process which has high moisture content is conducted to the super-heat steam generator, where this waste steam is burnt at higher than $700{ }^{\circ} \mathrm{C}$ and emitted under high temperature oxidization in an odorless condition. When the moisture content of the dried material reaches a specific value, a thermo-sensor sends a signal that automatically stops the unit, and the dried product can be obtained [19]. High-speed drying required significantly lower drying time (90 min) compared to freeze drying $(24 \mathrm{~h})$ and the extracts obtained from the high-speed dried citrus byproducts showed a high content of polymethoxylated flavones and flavanones, as well as strong radical scavenging activity and lipid peroxidation inhibition [19]. High-speed drying requires slightly higher drying times compared to microwave drying. However, during microwave drying, a thermal degradation of some polyphenols may occur, because of the heat developed during the microwave process [60]. Moreover, high microwave powers may lead to the formation of Maillard reaction products, resulting in a color change of the dried material [34, 49].

\subsection{Infrared and far-infrared drying}

Infrared is an electromagnetic irradiation and based on its wavelength is divided in nearinfrared (NIR; 0.78-1.4 mm), middle-infrared (MIR; 1.4-3 mm) and far-infrared (FIR; 3-1,000 $\mathrm{mm}$ ) [61]. Infrared drying has been employed for the dehydration of food products and becomes popular because of its various advantages, including energy savings, shorter drying 
time, high-quality dried products, uniform temperature distribution, and clean operational environment [61, 62]. Kammoun Bejar, Ghanem, Mihoubi, Kechaou and Boudhrioua Mihoubi [17] investigated the effect of different infrared-drying temperatures on the recovery of TPC from orange peels and found that the TPC yields of the extracts obtained from the infrared dried peels were significantly lower than those obtained from the fresh ones. It was mentioned that in the dried materials, all the plant cell components adhered together decreasing the surface area being exposed to the solvent [17]. Therefore, the accessibility of the analyte to the extraction solvent decreased resulting in reduced TPC yields [63]. Senevirathne, Kim, Kim, Oh, Oh, Ahn, Je, Lee and Jeon [18] employed far-infrared drying at different temperatures (40, $50,60,70$, and $80^{\circ} \mathrm{C}$ ) for converting wet citrus press-cakes into dried and obtained a varied effect on the individual and total phenolic compounds. For instance, the TPC, nobiletin, sinensetin, 3', 4',7,8-tetramethoxy flavone, and tangeretin contents of the extracts obtained from the far-infrared dried cakes were lower than those obtained from the freeze dried ones. However, higher retention of neohesperidin, narirutin, and quercetagetin was observed in the samples dried by far-infrared drying compared to those dried by freeze drying [18]. The heat being generated due to the far-infrared irradiation may lead to the cleavage of some polyphenols being linked to the cell wall polymers, facilitating higher recovery of the free forms, however, at the same time the liberated polyphenols may be degraded due to the formation of reactive oxygen species as a result of far-infrared irradiation [18].

\section{Post-drying treatments for liberating bound polyphenols}

Recent studies have indicated that higher extraction yields of individual phenolic compounds and antioxidant capacity could be achieved by further applying heat (conventional oven and microwave oven) or irradiation (UV and electron beam) treatments on the dried citrus by-products prior to extraction [22, 23, 25, 26, 64] (Table 5). 


\subsection{Heat treatment}

Phenolic compounds contained in citrus peels include phenolic acids (hydroxyl cinnamic acids) [65] and flavonoids (flavanones, flavones, and flavonols) [66]. In citrus peels, phenolic acids are often linked to various plant components through ester and glucoside bonds [64], whereas flavonoids can be present in the free (aglycones) or bound (glycoside) forms, with the free forms having higher antioxidant properties compared to the bound ones. The application of heat on the dried citrus by-products may enhance the liberation of polyphenols by breaking down both ester and glucoside bonds [23, 24, 26]. Both ester and glucoside bonds are types of covalent bonds and they tend to be very stable because the energies required to break them are higher than the thermal energy which is available at ambient temperature [67]. Therefore, as the temperature increases the thermal energy increases facilitating the cleavage of covalent bonds, hence the liberation of bound polyphenols. However, high temperatures may result in the formation of Maillard reaction products [49], changing the color of the material [34]. To date, heat has been applied either by the use of conventional or microwave ovens. The advantages and disadvantages of each method are discussed in the following sections.

\subsubsection{Conventional oven}

Jeong, Kim, Kim, Jo, Nam, Ahn and Lee [26] treated the dried peels of Citrus unshiu at different temperatures $\left(50,100\right.$, or $\left.150{ }^{\circ} \mathrm{C}\right)$ for different intervals using an electric muffle furnace and found that both temperature and time had a significant effect on their TPC. The extracts of dried citrus peels treated at $150{ }^{\circ} \mathrm{C}$ for $40 \mathrm{~min}$ had higher TPC and radical scavenging activity $(171.0 \mu \mathrm{M}$ and $59.73 \%$, respectively) compared to unheated control $(71.8$ $\mu \mathrm{M}$ and 29.64\%). The GC-MS chromatograms revealed the formation of several low molecular weight phenolic compounds in the heat treated samples, including 2,3-diacetyl-1- 
phenylnaphthalene, ferulic acid, vanillic acid among others (Fig. 4). During heat treatment, both ester and glucoside bonds can be broken down resulting in the liberation of the bound polyphenols. At the same time, heat may lead to polyphenol transformation explaining why the content of some phenolic compounds increases while the content of others decreases [27]. Similar results were reported by $\mathrm{Xu}, \mathrm{Ye}$, Chen and Liu [64] who treated the hot air dried peels of huyou (Citrus paradisi Changshanhuyou) at different temperatures and intervals using a conventional oven. The authors reported that heat treatment resulted in the release of phenolic acids, since the free fraction of both benzoic and cinnamic phenolic acids increased, while ester, glycoside, and ester bound fractions decreased, indicating that heat treatment of dried citrus by-products facilitates the breakdown of both ester and glucoside bonds. On the other hand, heat treatment negatively affected the content of flavanone glycosides (narirutin, naringin, hesperidin, and neohesperidin), implying that flavanones are vulnerable to heat treatment. According to the previous results, heat treatment could be effectively applied for liberating and enhancing the recovery yields of polyphenols from citrus by-products. However, high temperatures may lead to the degradation of some flavonoid compounds. Therefore, the heat treatment conditions should be carefully selected considering the type of polyphenols are aimed to be extracted.

\subsubsection{Microwave}

Microwave ovens have been mainly used for the extraction of bioactive compounds from plant matrices $[68,69]$. However, recent studies revealed that microwave energy could be effectively applied for enhancing the recovery of polyphenols and antioxidants from citrus byproducts $[16,23,24]$. Due to their electromagnetic nature, microwave irradiation (frequency of 0.3 to $300 \mathrm{GHz}$ ) results in a reduced heating time compared to conventional heating techniques, because of the heating of individual elements of a material $[23,70]$. During the 
microwave treatment, the heat being generated in the dried material results in the cleavage of covalent bonds which lead to the liberation of the bound polyphenols [60].

Hayat, Zhang, Chen, Xia, Jia and Zhong [23] treated the sun dried citrus by-products with different microwave powers for different intervals. Both microwave power and treatment time significantly affected the contents of individual phenolic acids. The free forms of phenolic acids increased with increasing microwave power, whereas the bound forms of phenolic acids declined, revealing liberation of the bound forms of phenolic acids due to the heat caused by the microwave energy. The authors made the assumption that the release of phenolic acids could be attributed either to the selective heating of some of the individual phenolic acids in the microwave field or to the physical forces acting between phenolic acids and plant matrix. Phenolic acids are linked to plant matrix through covalent bonds. The application of microwave irradiation results in the heat generation which leads to the cleavage of the bound phenolics [67]. Future studies investigating the exact mechanism implicated in the liberation of individual phenolic compounds from the plant tissues should be conducted for elucidating the mechanism of action.

Apart from liberating phenolic acids, microwave treatment could be effectively applied for enhancing the recovery of flavonoids (flavanols, flavanones, and flavonols) from dried citrus by-products [23]. Microwave treatment of $250 \mathrm{~W}$ for $10 \mathrm{~min}$ was proved to significantly enhance the recovery of catechin, naringin, rutin, kaempferol, and hesperidin from the sun dried citrus by-products [23]. However, the recovery yields of the individual flavonoids decreased when the citrus by-products were treated for a longer time at $250 \mathrm{~W}$. The heat which is generated as a result of the microwave irradiation results in the cleavage of the bound polyphenols and the cell wall rupture, leading to greater polyphenol yields $[16,23]$. At the same time prolong exposure to microwave irradiation may result in the thermal degradation or conversion of the liberated flavonoids [71]. These results are in accordance with a recent study 
which reported that appropriate microwave treatment of freeze dried lemon by-products resulted in higher recovery of TPC, TF, proanthocyanidins, and antioxidants [24]. The increased antioxidant capacity of the extracts obtained from the microwave treated citrus byproducts could be due to the release of the bound polyphenols, as well as to the formation of Maillard reaction products which are compounds with antioxidant properties [71].

\subsection{Irradiation}

\subsubsection{Ultraviolet $\mathrm{C}(\mathrm{UV}-\mathrm{C})$ irradiation}

UV-C (200-280 $\mathrm{nm})$ is a nonionizing, electromagnetic irradiation that has been shown to promote the accumulation of polyphenols and antioxidants in fresh fruits and vegetables [72, 73]. The effect of UV-C irradiation on the recovery of polyphenols and antioxidants from freeze dried lemon by-product was examined [25]. Freeze dried lemon by-products were subjected to different UV-C irradiations, and the results showed that the recovery of TPC and TF increased by 19 and 28\%, respectively, when the dried by-products were treated with UVC irradiation of $19 \mathrm{~kJ} / \mathrm{m}^{2}$ and $180 \mathrm{~kJ} / \mathrm{m}^{2}$, respectively, compared to the control (untreated dried by-products). The higher TPC and TF yields could be attributed to the cleavage of the bound polyphenols caused by heating effects due to the transfer of energy of many photons. Given that the previous study reported the effect of UV-C irradiation only on the recovery of total polyphenols, more studies should be conducted for elucidating the mechanism and UV-C effect on the recovery of individual phenolic compounds from dried citrus by-products. Although UV-C irradiation may positively affect the recovery of polyphenols from citrus by-products, a number of adverse effects of UV irradiation on human health have been identified and should be considered when this technology is employed. Personnel exposed to UV irradiation may suffer, eye damage, erythema, and immunosuppression, while chronic exposure of the skin to the UV irradiation may cause skin cancer [74, 75]. 


\subsubsection{Electron-beam irradiation (EBI)}

EBI is a low dose ionizing irradiation that has been used in the food and pharmaceutical industries for eliminating microbial contamination [76]. EBI has been characterized as a safe technology with no potential health risks [76]. The effect of EBI on the phytochemicals of fresh plant tissues has been previously reported [77]. Kim, Lee, Lee, Nam and Lee [22] treated the freeze dried by-product of Citrus unshiu with five EBI dosages (3.0, 5.6, 10.9, 25.5, and 37.9 $\mathrm{kGy}$ ) and showed that when the freeze dried powder was treated at $37.9 \mathrm{kGy}$, the TPC, and the radical scavenging activity of the water extracts increased from 6543.2 to $7405.4 \mathrm{mM}$, and $37.6 \%$ to $52.9 \%$, respectively, compared to the control (nonirradiated dried by-product). These results were attributed to the liberation of some phenolic compounds due to heating effect in the treated dried by-products because of the EBI since previous studies have reported the liberation of individual phenolic compounds (phenolic acids) as a result of heat treatment [23]. However, during electron beam irradiation the bound polyphenols might be liberated due to the energy of individual photons which is enough to break chemical bonds [28]. Future studies should be conducted in order to elucidate the mechanism implicated in the liberation and recovery of individual polyphenols (phenolic acids and flavonoids) from plant materials during EBI treatment.

\section{Conclusions and future trends}

Citrus by-products are usually exposed to undesirable environmental conditions for a long time after juice production and an important reduction in their polyphenol content may occur during this period. Future studies should investigate and determine the level of polyphenol degradation as a result of citrus by-product exposure to undesirable environmental conditions prior to material dehydration. Drying is a crucial but not compulsory step that 
precedes the extraction process of bioactive compounds from citrus by-products. The advantages of citrus by-product dehydration include i) reduced packaging volume, hence lower transportation cost and storage space requirements, ii) prevention of material spoilage, and iii) prevention of polyphenol enzymatic degradation.

Several parameters should be considered for the selection of the drying technique, including energy consumption, residual moisture content in the dried material, and retention of bioactive compounds in the dried product. Several methods have been employed for drying citrus by-products, such as freeze drying, hot-air drying, vacuum drying, sun drying, with each drying technique having its own advantages and limitations. Generally, freeze drying is considered as the most efficient but expensive drying technique. Freeze drying results in high retention levels of flavonoids and phenolic acids in citrus by-products. However, a number of studies have indicated that hot-air drying at high temperatures may result in dried citrus materials with higher phenolic acid and flavonoid contents than those dried by freeze drying. For instance, ferulic acid, $p$-coumaric acid, and gallic acid recovery could be higher in the extracts of citrus by-products dried by hot-air drying than those dried by freeze drying. Although hot-air drying at high temperatures may promote the recovery of some phenolic compounds, lower hot-air drying temperatures may result in a significant enzymatic degradation of polyphenols, due to material exposure to oxygen for long times. When citrus wastes are dried at low temperatures, a rapid polyphenol degradation may occur during the first hour of the process. This loss might be prevented by the application of some treatments prior to hot-air drying, such as osmotic dehydration of the citrus by-product. Future studies should take into consideration the periods during hot-air drying that polyphenols are degraded and try to minimize polyphenol reduction by applying treatments prior to extraction for inactivating enzymes implicated in polyphenol degradation. Vacuum drying is a technique that takes place in the absence of oxygen and at lower temperatures compared to hot-air drying, preventing the 
degradation of polyphenols being vulnerable to oxygen and heat exposure. Although several comparison studies have been conducted on citrus by-products, only a few have included the effect of vacuum drying on polyphenol retention.

To date, some new drying techniques have been applied for drying citrus by-products, including, microwave drying, infrared drying, far-infrared drying, and high-speed drying. Among others, high-speed drying seems to be the most effective since it results in a dried product with low moisture content, and high retention of polyphenols in a significantly shorter time than freeze drying. On the other hand, although both microwave and infrared drying require shorter times for drying citrus by-products compared to freeze drying, the retention of polyphenols in the microwave and infrared dried citrus by-products is significantly lower compared to those dried by freeze drying. Some comparisons of different drying methods have been performed, however, they remain partial since only two or three methods are compared in the same work. Although several studies have been conducted investigating the effect of different drying treatments on the retention of polyphenols in citrus by-products, only a few have provided information about the degradation kinetics of individual phenolic compounds during the drying process. The degradation kinetics of individual phenolic compounds during drying process will facilitate the development of the optimum drying conditions for high retention of polyphenols in the dried material.

Recently, studies have been conducted investigating the effect of different treatments of the dried citrus by-products on the liberation of bound polyphenols. Microwave could be effectively used for liberating phenolic acids from dried citrus by-products; however, the exact mechanism implicated in the liberation of individual phenolic compounds from the plant tissues needs clarification. Other treatments, such as UV-C or EBI could be applied on dried citrus by-products for enhancing their phenolic content and antioxidant activities. Studies 
investigating the effect of these treatments on the retention of individual polyphenols are recommended.

\section{Acknowledgements}

The author thanks to the University of Newcastle and Australian Research Council (ARC)

Training Centre for Food and Beverage Supply Chain Optimisation (IC140100032) for research funding the $\mathrm{PhD}$ scholarship to Konstantinos Papoutsis.

\section{Conflict of interest statement}

The authors declare no conflict of interest.

\section{References}

[1] FAO, Intergovernmental Group on Citrus Fruits. A Subsidiary Body of the FAO Committee on Commodity Problems (CCP) Rome, 2016.

[2] F. Lanuzza, F. Mondello, M.M. Tripodo, Studies About the Utilization of Citrus Wastes in View of Environment Protection, in: R. Salomone, G. Saija (Eds.), Pathways to Environmental Sustainability: Methodologies and Experiences, Springer International Publishing, Cham, 2014, pp. 147-156. [3] M.Z. Islam, Y. Kitamura, M. Kokawa, K. Monalisa, F.-H. Tsai, S. Miyamura, Effects of micro wet milling and vacuum spray drying on the physicochemical and antioxidant properties of orange (Citrus unshiu) juice with pulp powder, Food and Bioproducts Processing 101(Supplement C) (2017) 132144.

[4] M.J. Dhanavade, C.B. Jalkute, J.S. Ghosh, K.D. Sonawane, Study Antimicrobial Activity of Lemon (Citrus lemon L.) Peel Extract, Br. J. Pharmacol. Toxicol. 2(3) (2011) 119-122.

[5] A. Ortuño, A. Báidez, P. Gómez, M.C. Arcas, I. Porras, A. García-Lidón, J.A.D. Río, Citrus paradisi and Citrus sinensis flavonoids: Their influence in the defence mechanism against Penicillium digitatum, Food chemistry 98(2) (2006) 351-358.

[6] N.E. Rawson, C.-T. Ho, S. Li, Efficacious anti-cancer property of flavonoids from citrus peels, Food Science and Human Wellness 3(3-4) (2014) 104-109.

[7] K. Papoutsis, P. Pristijono, J.B. Golding, C.E. Stathopoulos, M.C. Bowyer, C.J. Scarlett, Q.V. Vuong, Optimisation of aqueous extraction conditions for the recovery of phenolic compounds and antioxidants from lemon pomace, Int J Food Sci Tech 51(9) (2016) 2009-2018.

[8] P.K. Wilmsen, D.S. Spada, M. Salvador, Antioxidant Activity of the Flavonoid Hesperidin in Chemical and Biological Systems, J. Agric. Food Chem. 53(12) (2005) 4757-4761.

[9] Y. Sun, Y. Shen, D. Liu, X. Ye, Effects of drying methods on phytochemical compounds and antioxidant activity of physiologically dropped un-matured citrus fruits, LWT - Food Science and Technology 60(2, Part 2) (2015) 1269-1275.

[10] K. Papoutsis, P. Pristijono, J.B. Golding, C.E. Stathopoulos, M.C. Bowyer, C.J. Scarlett, Q.V. Vuong, Effect of vacuum-drying, hot air-drying and freeze-drying on polyphenols and antioxidant capacity of lemon (Citrus limon) pomace aqueous extracts, International Journal of Food Science \& Technology 52(4) (2017) 880-887. 
[11] G.I. Jenkins, Signal transduction in responses to UV-B radiation, Annual review of plant biology 60 (2009) 407-31.

[12] J. Dai, R.J. Mumper, Plant phenolics: extraction, analysis and their antioxidant and anticancer properties, Molecules 15(10) (2010) 7313-52.

[13] E. González-Molina, R. Domínguez-Perles, D.A. Moreno, C. García-Viguera, Natural bioactive compounds of Citrus limon for food and health, Journal of Pharmaceutical and Biomedical Analysis 51(2) (2010) 327-345.

[14] O. Benavente-García, J. Castillo, F.R. Marin, A. Ortuño, J.A. Del Río, Uses and Properties of Citrus Flavonoids, Journal of agricultural and food chemistry 45(12) (1997) 4505-4515.

[15] R.J. Robbins, Phenolic Acids in Foods: An Overview of Analytical Methodology, Journal of agricultural and food chemistry 51(10) (2003) 2866-2887.

[16] K. Hayat, X. Zhang, U. Farooq, S. Abbas, S. Xia, C. Jia, F. Zhong, J. Zhang, Effect of microwave treatment on phenolic content and antioxidant activity of citrus mandarin pomace, Food chemistry 123(2) (2010) 423-429.

[17] A. Kammoun Bejar, N. Ghanem, D. Mihoubi, N. Kechaou, N. Boudhrioua Mihoubi, Effect of Infrared Drying on Drying Kinetics, Color, Total Phenols and Water and Oil Holding Capacities of Orange (Citrus Sinensis) Peel and Leaves, International Journal of Food Engineering 7(5) (2011). [18] M. Senevirathne, S.-H. Kim, Y.-D. Kim, C.-K. Oh, M.-C. Oh, C.-B. Ahn, J.-Y. Je, W.-W. Lee, Y.-J. Jeon, Effect of far-infrared radiation drying of citrus press-cakes on free radical scavenging and antioxidant activities, Journal of Food Engineering 97(2) (2010) 168-176.

[19] M. Senevirathne, Y.-J. Jeon, J.-H. Ha, S.-H. Kim, Effective drying of citrus by-product by high speed drying: A novel drying technique and their antioxidant activity, Journal of Food Engineering 92(2) (2009) 157-163.

[20] S. Abhay, C. Hii, C. Law, S. Suzannah, M. Djaeni, Effect of hot-air drying temperature on the polyphenol content and the sensory properties of cocoa beans, International Food Research Journal 23(4) (2016).

[21] I. Volf, I. Ignat, M. Neamtu, V.I. Popa, Thermal stability, antioxidant activity, and photo-oxidation of natural polyphenols, Chemical Papers 68(1) (2014) 121-129.

[22] J.-W. Kim, B.C. Lee, J.-H. Lee, K.-C. Nam, S.-C. Lee, Effect of electron-beam irradiation on the antioxidant activity of extracts from Citrus unshiu pomaces, Radiation Physics and Chemistry 77(1) (2008) 87-91.

[23] K. Hayat, X. Zhang, H. Chen, S. Xia, C. Jia, F. Zhong, Liberation and separation of phenolic compounds from citrus mandarin peels by microwave heating and its effect on antioxidant activity, Separation and Purification Technology 73(3) (2010) 371-376.

[24] K. Papoutsis, P. Pristijono, J.B. Golding, C.E. Stathopoulos, M.C. Bowyer, C.J. Scarlett, Q.V. Vuong, Enhancement of the total phenolic compounds and antioxidant activity of aqueous Citrus limon L. pomace extract using microwave pretreatment on the dry powder, Journal of Food Processing and Preservation DOI 10.1111/jfpp.13152 in press (2016).

[25] K. Papoutsis, Q.V. Vuong, P. Pristijono, J.B. Golding, M.C. Bowyer, C.J. Scarlett, C.E. Stathopoulos, Enhancing the Total Phenolic Content and Antioxidants of Lemon Pomace Aqueous Extracts by Applying UV-C Irradiation to the Dried Powder, Foods 5(3) (2016) 55.

[26] S.M. Jeong, S.Y. Kim, D.R. Kim, S.C. Jo, K.C. Nam, D.U. Ahn, S.C. Lee, Effect of heat treatment on the antioxidant activity of extracts from citrus peels, Journal of agricultural and food chemistry 52(11) (2004) 3389-3393.

[27] N. Buchner, A. Krumbein, S. Rohn, L.W. Kroh, Effect of thermal processing on the flavonols rutin and quercetin, Rapid Communications in Mass Spectrometry 20(21) (2006) 3229-3235.

[28] T. Tokunaga, T. Narushima, T. Yonezawa, T. Sudo, S. Okubo, S. Komatsubara, K. Sasaki, T. Yamamoto, Temperature distributions of electron beam-irradiated samples by scanning electron microscopy, Journal of Microscopy 248(3) (2012) 228-233.

[29] N. M'Hiri, I. Ioannou, M. Ghoul, N.M. Boudhrioua, Extraction Methods of Citrus Peel Phenolic Compounds, Food Reviews International 30(4) (2014) 265-290. 
[30] K. Sharma, N. Mahato, M.H. Cho, Y.R. Lee, Converting citrus wastes into value-added products: Economic and environmently friendly approaches, Nutrition 34 (2017) 29-46.

[31] P. Putnik, D. Bursać Kovačević, A. Režek Jambrak, F. Barba, G. Cravotto, A. Binello, J. Lorenzo, A. Shpigelman, Innovative "Green" and Novel Strategies for the Extraction of Bioactive Added Value Compounds from Citrus Wastes-A Review, Molecules 22(5) (2017) 680.

[32] Y. Sui, J. Yang, Q. Ye, H. Li, H. Wang, Infrared, Convective, and Sequential Infrared and Convective Drying of Wine Grape Pomace, Drying Technology 32(6) (2014) 686-694.

[33] M.A. Delele, F. Weigler, J. Mellmann, Advances in the Application of a Rotary Dryer for Drying of Agricultural Products: A Review, Drying Technology 33(5) (2015) 541-558.

[34] H.-H. Chen, C.E. Hernandez, T.-C. Huang, A study of the drying effect on lemon slices using a closed-type solar dryer, Solar Energy 78(1) (2005) 97-103.

[35] N.A. Salazar, C. Alvarez, C.E. Orrego, Optimization of Freezing Parameters for Freeze-Drying Mango (Mangifera indica L.) Slices, Drying Technology (2017) null-null.

[36] S.M. Tasirin, I. Puspasari, A.Z. Sahalan, M. Mokhtar, M.K.A. Ghani, Z. Yaakob, Drying of Citrus sinensis Peels in an Inert Fluidized Bed: Kinetics, Microbiological Activity, Vitamin C, and Limonene Determination, Drying Technology 32(5) (2014) 497-508.

[37] N. Ghanem Romdhane, C. Bonazzi, N. Kechaou, N.B. Mihoubi, Effect of Air-Drying Temperature on Kinetics of Quality Attributes of Lemon (Citrus limon cv. lunari) Peels, Drying Technology 33(13) (2015) 1581-1589.

[38] G.D.J. Adams, FREEZE-DRYING OF BIOLOGICAL MATERIALS, Drying Technology 9(4) (1991) 891925.

[39] M.-L. Chen, D.-J. Yang, S.-C. Liu, Effects of drying temperature on the flavonoid, phenolic acid and antioxidative capacities of the methanol extract of citrus fruit (Citrus sinensis (L.) Osbeck) peels, International Journal of Food Science \& Technology 46(6) (2011) 1179-1185.

[40] S.-N. Lou, Y.-S. Hsu, C.-T. Ho, Flavonoid compositions and antioxidant activity of calamondin extracts prepared using different solvents, Journal of Food and Drug Analysis 22(3) (2014) 290-295.

[41] C.A. Ledesma-Escobar, F. Priego-Capote, M.D. Luque de Castro, Comparative Study of the Effect of Sample Pretreatment and Extraction on the Determination of Flavonoids from Lemon (Citrus limon), PloS one 11(1) (2016) e0148056.

[42] A.D. Assefa, Y.S. Keum, Effect of extraction solvent and various drying methods on polyphenol content and antioxidant activities of yuzu (Citrus junos Sieb ex Tanaka), Journal of Food Measurement and Characterization 11(2) (2017) 576-585.

[43] S.-N. Lou, Y.-C. Lai, J.-D. Huang, C.-T. Ho, L.-H.A. Ferng, Y.-C. Chang, Drying effect on flavonoid composition and antioxidant activity of immature kumquat, Food chemistry 171 (2015) 356-363.

[44] C.A. Ledesma-Escobar, F. Priego-Capote, M.D. Luque de Castro, Effect of sample pretreatment on the extraction of lemon (Citrus limon) components, Talanta 153 (2016) 386-391.

[45] S.-N. Lou, Y.-S. Lin, Y.-S. Hsu, E.M. Chiu, C.-T. Ho, Soluble and insoluble phenolic compounds and antioxidant activity of immature calamondin affected by solvents and heat treatment, Food chemistry 161 (2014) 246-253.

[46] C.I. Delgado-Nieblas, J.J. Zazueta-Morales, J.A. Ahumada-Aguilar, E. Aguilar-Palazuelos, A. Carrillo-López, N. Jacobo-Valenzuela, J. Telis-Romero, Optimization of an Air-Drying Process to Obtain a Dehydrated Naranjita (Citrus Mitis B.) Pomace Product With High Bioactive Compounds and Antioxidant Capacity, Journal of Food Process Engineering 40(1) (2017) e12338-n/a.

[47] M.C. Garau, S. Simal, C. Rosselló, A. Femenia, Effect of air-drying temperature on physicochemical properties of dietary fibre and antioxidant capacity of orange (Citrus aurantium $v$.

Canoneta) by-products, Food chemistry 104(3) (2007) 1014-1024.

[48] M. McSweeney, K. Seetharaman, State of Polyphenols in the Drying Process of Fruits and Vegetables, Critical Reviews in Food Science and Nutrition 55(5) (2015) 660-669.

[49] V. Lavelli, C. Pompei, M.A. Casadei, Quality of nectarine and peach nectars as affected by lyepeeling and storage, Food chemistry 115(4) (2009) 1291-1298. 
[50] S. Rohn, N. Buchner, G. Driemel, M. Rauser, L.W. Kroh, Thermal Degradation of Onion Quercetin Glucosides under Roasting Conditions, Journal of agricultural and food chemistry 55(4) (2007) 15681573.

[51] A.R. Rechner, J.P.E. Spencer, G. Kuhnle, U. Hahn, C.A. Rice-Evans, Novel biomarkers of the metabolism of caffeic acid derivatives in vivo, Free Radical Biology and Medicine 30(11) (2001) 12131222.

[52] R. Bal, B.B. Tope, S. Sivasanker, Vapour phase O-methylation of dihydroxy benzenes with methanol over cesium-loaded silica, a solid base, Journal of Molecular Catalysis A: Chemical 181(1) (2002) 161-171.

[53] N. M'hiri, I. Ioannou, M. Ghoul, N.M. Boudhrioua, Proximate chemical composition of orange peel and variation of phenols and antioxidant activity during convective air drying, Journal of New Sciences (2015).

[54] N. Ghanem Romdhane, N. Djendoubi, C. Bonazzi, N. Kechaou, N. Boudhrioua Mihoubi, Effect of Combined Air-Drying-Osmotic Dehydration on Kinetics of Techno-functional Properties, Color and Total Phenol Contents of Lemon (Citrus limon. v. lunari) Peels, International Journal of Food Engineering, 2016, p. 515.

[55] I. Alibas, Microwave, Vacuum, and Air Drying Characteristics of Collard Leaves, Drying Technology 27(11) (2009) 1266-1273.

[56] S. Jaya, H. Das, A Vacuum Drying Model for Mango Pulp, Drying Technology 21(7) (2003) 12151234.

[57] Z. Zoric, V. Dragovic-Uzelac, S. Pedisic, Z. Kurtanjek, I.E. Garofulic, Kinetics of the degradation of anthocyanins, phenolic acids and flavonols during heat treatments of freeze-dried sour cherry Marasca paste, Food Technology and Biotechnology 52(1) (2014) 101.

[58] G.R.z. Díaz, J. Martínez-Monzó, P. Fito, A. Chiralt, Modelling of dehydration-rehydration of orange slices in combined microwave/air drying, Innovative Food Science \& Emerging Technologies $4(2)$ (2003) 203-209.

[59] N. Ghanem, D. Mihoubi, N. Kechaou, N.B. Mihoubi, Microwave dehydration of three citrus peel cultivars: Effect on water and oil retention capacities, color, shrinkage and total phenols content, Industrial Crops and Products 40(Supplement C) (2012) 167-177.

[60] A. Kammoun Bejar, N. Kechaou, N. Boudhrioua Mihoubi, Effect of microwave treatment on physical and functional properties of orange (Citrus sinensis) peel and leaves, Journal of Food Processing \& Technology 2(02) (2011) 109-116.

[61] M.H. Riadh, S.A.B. Ahmad, M.H. Marhaban, A.C. Soh, Infrared Heating in Food Drying: An Overview, Drying Technology 33(3) (2015) 322-335.

[62] D. Nowak, P.P. Lewicki, Infrared drying of apple slices, Innovative Food Science \& Emerging Technologies 5(3) (2004) 353-360.

[63] D.L. Luthria, Influence of experimental conditions on the extraction of phenolic compounds from parsley (Petroselinum crispum) flakes using a pressurized liquid extractor, Food chemistry 107(2) (2008) 745-752.

[64] G. Xu, X. Ye, J. Chen, D. Liu, Effect of heat treatment on the phenolic compounds and antioxidant capacity of citrus peel extract, Journal of agricultural and food chemistry 55(2) (2007) 330-335.

[65] Y.Q. Ma, X.Q. Ye, Z.X. Fang, J.C. Chen, G.H. Xu, D.H. Liu, Phenolic compounds and antioxidant activity of extracts from ultrasonic treatment of satsuma mandarin (Citrus unshiu Marc.) peels, Journal of agricultural and food chemistry 56(14) (2008) 5682-5690.

[66] M. de Lourdes Mata Bilbao, C. Andrés-Lacueva, O. Jáuregui, R.M. Lamuela-Raventós, Determination of flavonoids in a Citrus fruit extract by LC-DAD and LC-MS, Food chemistry 101(4) (2007) 1742-1747.

[67] H. Lodish, A. Berk, S.L. Zipursky, P. Matsudaira, D. Baltimore, J. Darnell, Molecular cell biology 4th edition, National Center for Biotechnology InformationÕs Bookshelf (2000). 
[68] K. Hayat, S. Hussain, S. Abbas, U. Farooq, B. Ding, S. Xia, C. Jia, X. Zhang, W. Xia, Optimized microwave-assisted extraction of phenolic acids from citrus mandarin peels and evaluation of antioxidant activity in vitro, Separation and Purification Technology 70(1) (2009) 63-70.

[69] B. Nayak, F. Dahmoune, K. Moussi, H. Remini, S. Dairi, O. Aoun, M. Khodir, Comparison of microwave, ultrasound and accelerated-assisted solvent extraction for recovery of polyphenols from Citrus sinensis peels, Food chemistry 187 (2015) 507-516.

[70] B. Kaufmann, P. Christen, J.L. Veuthey, Parameters Affecting Microwave-assisted Extraction of Withanolides, Phytochemical Analysis 12 (2001) 327-331.

[71] K. Sharma, E.Y. Ko, A.D. Assefa, S. Ha, S.H. Nile, E.T. Lee, S.W. Park, Temperature-dependent studies on the total phenolics, flavonoids, antioxidant activities, and sugar content in six onion varieties, Journal of Food and Drug Analysis 23(2) (2015) 243-252.

[72] P. Perkins-Veazie, J.K. Collins, L. Howard, Blueberry fruit response to postharvest application of ultraviolet radiation, Postharvest Biol. Tec. 47(3) (2008) 280-285.

[73] C.-h. Liu, L.-y. Cai, X.-y. Lu, X.-x. Han, T.-j. Ying, Effect of Postharvest UV-C Irradiation on Phenolic Compound Content and Antioxidant Activity of Tomato Fruit During Storage, Journal of Integrative Agriculture 11(1) (2012) 159-165.

[74] A.R. Young, Acute effects of UVR on human eyes and skin, Progress in Biophysics and Molecular Biology 92(1) (2006) 80-85.

[75] S.K. Katiyar, H.C. Pal, R. Prasad, Dietary proanthocyanidins prevent ultraviolet radiation-induced non-melanoma skin cancer through enhanced repair of damaged DNA-dependent activation of immune sensitivity, Seminars in Cancer Biology 46(Supplement C) (2017) 138-145.

[76] H.-M. Lung, Y.-C. Cheng, Y.-H. Chang, H.-W. Huang, B.B. Yang, C.-Y. Wang, Microbial decontamination of food by electron beam irradiation, Trends in Food Science \& Technology 44(1) (2015) 66-78.

[77] Â. Fernandes, A.L. Antonio, M.B.P.P. Oliveira, A. Martins, I.C.F.R. Ferreira, Effect of gamma and electron beam irradiation on the physico-chemical and nutritional properties of mushrooms: $A$ review, Food chemistry 135(2) (2012) 641-650.

[78] V. Goulas, G.A. Manganaris, Exploring the phytochemical content and the antioxidant potential of Citrus fruits grown in Cyprus, Food chemistry 131(1) (2012) 39-47.

[79] A. Bermejo, M.J. Llosá, A. Cano, Analysis of Bioactive Compounds in Seven Citrus Cultivars, Food Science and Technology International 17 (2011) 55-62.

[80] Y. Sun, J. Wang, S. Gu, Z. Liu, Y. Zhang, X. Zhang, Simultaneous Determination of Flavonoids in Different Parts of Citrus reticulata 'Chachi' Fruit by High Performance Liquid ChromatographyPhotodiode Array Detection, Molecules 15 (2010) 5378-5388.

[81] Y.-C. Wang, Y.-C. Chuang, H.-W. Hsu, The flavonoid, carotenoid and pectin content in peels of citrus cultivated in Taiwan, Food chemistry 106(1) (2008) 277-284.

[82] D. Ramful, T. Bahorun, E. Bourdon, E. Tarnus, O.I. Aruoma, Bioactive phenolics and antioxidant propensity of flavedo extracts of Mauritian citrus fruits: Potential prophylactic ingredients for functional foods application, Toxicology 278(1) (2010) 75-87.

[83] A. Bocco, M.E. Cuvelier, H. Richard, C. Berset, Antioxidant Activity and Phenolic Composition of Citrus Peel and Seed Extracts, Journal of agricultural and food chemistry 46(6) (1998) 2123-2129.

[84] J.A. Del Río, M.D. Fuster, P. Gómez, I. Porras, A. García-Lidón, A. Ortuño, Citrus limon: a source of flavonoids of pharmaceutical interest, Food chemistry 84(3) (2004) 457-461.

[85] G.H. Xu, J. Chen, D.H. Liu, Y.H. Zhang, P. Jiang, X.Q. Ye, Minerals, phenolic compounds, and antioxidant capacity of citrus peel extract by hot water, Journal of food science 73 (2008) C11-8.

[86] Y.-C. Wang, Y.-C. Chuang, Y.-H. Ku, Quantitation of bioactive compounds in citrus fruits cultivated in Taiwan, Food chemistry 102(4) (2007) 1163-1171.

[87] Y.-Q. Ma, J.-C. Chen, D.-H. Liu, X.-Q. Ye, Simultaneous extraction of phenolic compounds of citrus peel extracts: Effect of ultrasound, Ultrasonics Sonochemistry 16(1) (2009) 57-62. 
[88] H. Peleg, M. Naim, R.L. Rouseff, U. Zehavi, Distribution of bound and free phenolic acids in oranges (Citrus sinensis) and Grapefruits (Citrus paradisi), Journal of the science of food and agriculture 57(3) (1991) 417-426.

[89] A. Wojdyło, A. Figiel, K. Lech, P. Nowicka, J. Oszmiański, Effect of Convective and VacuumMicrowave Drying on the Bioactive Compounds, Color, and Antioxidant Capacity of Sour Cherries, Food Bioprocess Technol 7(3) (2014) 829-841.

[90] C. Talens, J.C. Arboleya, M. Castro-Giraldez, P.J. Fito, Effect of microwave power coupled with hot air drying on process efficiency and physico-chemical properties of a new dietary fibre ingredient obtained from orange peel, LWT - Food Science and Technology 77 (2017) 110-118. 
Table 1. Flavonoid contents of the peels of different citrus species.

\begin{tabular}{|c|c|c|c|c|}
\hline Flavonoids & Citrus species & Quantity & Drying technique applied & Refs \\
\hline \multicolumn{5}{|l|}{ Flavanones } \\
\hline Hesperidin & $\begin{array}{l}\text { Orange } \\
\text { Orange } \\
\text { Grapefruit } \\
\text { Mandarin } \\
\text { Mandarin } \\
\text { C. tankan Hayata }\end{array}$ & $\begin{array}{l}66.10 \mathrm{mg} / \mathrm{g} \mathrm{d.w.}{ }^{1} \\
30.17-39.09 \mathrm{mg} / \mathrm{g} \mathrm{d.w}^{2} \\
1.67-3.87 \mathrm{mg} / \mathrm{g} \text { d.w. } \\
55.26 \mathrm{mg} / \mathrm{g}^{3} \\
29.5 \mathrm{mg} / \mathrm{g} \mathrm{d} . w .^{4} \\
23.4 \mathrm{mg} / \mathrm{g} \mathrm{d} .{ }^{4}{ }^{4}\end{array}$ & $\begin{array}{l}\text { Freeze drying } \\
\text { Freeze drying } \\
\text { Freeze drying } \\
\text { Vacuum drying }\left(60{ }^{\circ} \mathrm{C}\right) \\
\text { Hot-air drying (below } 50{ }^{\circ} \mathrm{C} \text { ) } \\
\text { Hot-air drying (below } 50^{\circ} \mathrm{C} \text { ) }\end{array}$ & {$[78,79,78,80,81,81]$} \\
\hline Naringin & $\begin{array}{l}\text { Grapefruit } \\
\text { Mandarin } \\
\text { Lemon } \\
\text { Sour orange }\end{array}$ & $\begin{array}{l}4.04-5.91 \mathrm{mg} / \mathrm{g} \text { d.w. } \\
19.49 \mathrm{mg} / \mathrm{g} \mathrm{f.w} .^{1} \\
6.06 \mathrm{mg} / \mathrm{g} \text { d.w. }{ }^{4} \\
10.97 \mathrm{mg} / \mathrm{g} \mathrm{d.w} .^{4}\end{array}$ & $\begin{array}{l}\text { Freeze drying } \\
\text { Freeze drying } \\
\text { Hot-air drying }\left(40^{\circ} \mathrm{C}\right) \\
\text { Hot-air drying }\left(40^{\circ} \mathrm{C}\right)\end{array}$ & {$[78,82,83,83]$} \\
\hline Neoeriocitrin & $\begin{array}{l}\text { Lemon } \\
\text { Sour orange } \\
\text { Orange } \\
\text { Mandarin }\end{array}$ & $\begin{array}{l}6.12 \mathrm{mg} / \mathrm{g} \text { d.w. }{ }^{4} \\
3.80 \mathrm{mg} / \mathrm{g} \text { d.w. }{ }^{4} \\
8.80 \mathrm{mg} / \mathrm{g} \text { f.w. }{ }^{1} \\
34.65 \mathrm{mg} / \mathrm{g} \text { f.w. }\end{array}$ & $\begin{array}{l}\text { Hot-air drying }\left(40^{\circ} \mathrm{C}\right) \\
\text { Hot-air drying }\left(40^{\circ} \mathrm{C}\right) \\
\text { Freeze drying } \\
\text { Freeze drying }\end{array}$ & {$[83,83,82,82]$} \\
\hline Neohesperidin & $\begin{array}{l}\text { Sour orange } \\
\text { Lemon } \\
\text { Mandarin } \\
\text { Calamondin }\end{array}$ & $\begin{array}{l}6.62 \mathrm{mg} / \mathrm{g} \mathrm{d} . \mathrm{w} .{ }^{4} \\
4.37 \mathrm{mg} / \mathrm{g} \text { d.w. }{ }^{4} \\
7.09 \mathrm{mg} / \mathrm{g} \text { f.w. }{ }^{1} \\
3.49 \mathrm{mg} / \mathrm{g} \text { d.w. }{ }^{4}\end{array}$ & $\begin{array}{l}\text { Hot-air drying }\left(40^{\circ} \mathrm{C}\right) \\
\text { Hot-air drying }\left(40^{\circ} \mathrm{C}\right) \\
\text { Freeze drying } \\
\text { Freeze drying }\end{array}$ & {$[83,83,82,40]$} \\
\hline Narirutin & $\begin{array}{l}\text { Sour orange } \\
\text { Orange } \\
\text { Orange } \\
\text { Mandarin }\end{array}$ & $\begin{array}{l}0.25 \mathrm{mg} / \mathrm{g} \text { d.w. }{ }^{4} \\
16.52 \mathrm{mg} / \mathrm{g} \mathrm{f.w} .{ }^{1} \\
2.40-5.25 \mathrm{mg} / \mathrm{g} \text { d.w. }{ }^{2} \\
13.54 \mathrm{mg} / \mathrm{g} \text { f.w. }{ }^{1}\end{array}$ & $\begin{array}{l}\text { Hot-air drying }\left(40^{\circ} \mathrm{C}\right) \\
\text { Freeze drying } \\
\text { Freeze drying } \\
\text { Freeze drying }\end{array}$ & {$[83,82,79,82]$} \\
\hline Didymin & $\begin{array}{l}\text { Orange } \\
\text { Mandarin }\end{array}$ & $\begin{array}{l}1.10-1.69 \mathrm{mg} / \mathrm{g} \mathrm{d} . \mathrm{w}^{2} \\
0.31-1.23 \mathrm{mg} / \mathrm{g} \text { d.w. }\end{array}$ & $\begin{array}{l}\text { Freeze drying } \\
\text { Freeze drying }\end{array}$ & {$[79,79]$} \\
\hline
\end{tabular}




\begin{tabular}{|c|c|c|c|c|}
\hline \multicolumn{5}{|l|}{ Flavonols } \\
\hline Rutin & $\begin{array}{l}\text { Lemon } \\
\text { Orange } \\
\text { Orange } \\
\text { Mandarin }\end{array}$ & $\begin{array}{l}0.29 \mathrm{mg} / \mathrm{g} \mathrm{d.w}{ }^{4} \\
8.16 \mathrm{mg} / \mathrm{g} \mathrm{f.w} .^{1} \\
0.23 \mathrm{mg} / \mathrm{g} \mathrm{d.w}{ }^{4} \\
0.29 \mathrm{mg} / \mathrm{g} \mathrm{d.w}{ }^{4}\end{array}$ & $\begin{array}{l}\text { Hot-air drying (below } 50^{\circ} \mathrm{C} \text { ) } \\
\text { Freeze drying } \\
\text { Hot-air drying (below } 50^{\circ} \mathrm{C} \text { ) } \\
\text { Hot-air drying (below } 50^{\circ} \mathrm{C} \text { ) }\end{array}$ & {$[81,82,81,81]$} \\
\hline Quercetin & $\begin{array}{l}\text { Mandarin } \\
\text { Orange } \\
\text { Lemon }\end{array}$ & $\begin{array}{l}0.47 \mathrm{mg} / \mathrm{g} \mathrm{d.w} \cdot{ }^{4} \\
0.14 \mathrm{mg} / \mathrm{g} \text { d.w. }{ }^{4} \\
0.21 \mathrm{mg} / \mathrm{g} \mathrm{d.w} .\end{array}$ & $\begin{array}{l}\text { Hot-air drying (below } 50^{\circ} \mathrm{C} \text { ) } \\
\text { Hot-air drying (below } 50^{\circ} \mathrm{C} \text { ) } \\
\text { Hot-air drying (below } 50^{\circ} \mathrm{C} \text { ) }\end{array}$ & {$[81,81,81]$} \\
\hline Catechin & Mandarin & $0.02 \mathrm{mg} / \mathrm{g}$ d.w. ${ }^{3}$ & Sun drying & {$[16]$} \\
\hline Kaempferol & $\begin{array}{l}\text { Orange } \\
\text { Mandarin } \\
\text { Lemon }\end{array}$ & $\begin{array}{l}0.32 \mathrm{mg} / \mathrm{g} \mathrm{d} . \mathrm{w}^{4} \\
0.38 \mathrm{mg} / \mathrm{g} \mathrm{d} . \mathrm{w}^{4} \\
0.31 \mathrm{mg} / \mathrm{g} \mathrm{d} . \mathrm{w}^{4}\end{array}$ & $\begin{array}{l}\text { Hot-air drying (below } 50^{\circ} \mathrm{C} \text { ) } \\
\text { Hot-air drying (below } 50^{\circ} \mathrm{C} \text { ) } \\
\text { Hot-air drying (below } 50^{\circ} \mathrm{C} \text { ) }\end{array}$ & {$[81,81,81]$} \\
\hline \multicolumn{5}{|l|}{ Flavones } \\
\hline Diosmin & $\begin{array}{l}\text { Orange } \\
\text { Orange } \\
\text { Mandarin } \\
\text { Mandarin } \\
\text { Lemon }\end{array}$ & $\begin{array}{l}4.55 \mathrm{mg} / \mathrm{g} \mathrm{f.w.}{ }^{1} \\
0.49-0.53 \mathrm{mg} / \mathrm{g} \mathrm{d} . \mathrm{w}^{2} \\
6.29 \mathrm{mg} / \mathrm{g} \mathrm{f.w} .^{1} \\
1.02-1.40 \mathrm{mg} / \mathrm{g} \mathrm{d} . \mathrm{w}^{2} \\
3.30 \mathrm{mg} / \mathrm{g} \mathrm{d.w.}{ }^{1}\end{array}$ & $\begin{array}{l}\text { Freeze drying } \\
\text { Freeze drying } \\
\text { Freeze drying } \\
\text { Freeze drying } \\
\text { Hot-air drying }\left(50^{\circ} \mathrm{C}\right)\end{array}$ & {$[82,79,82,79,84]$} \\
\hline Tangeretin & $\begin{array}{l}\text { Calamondin } \\
\text { Orange } \\
\text { Mandarin } \\
\text { Satsuma mandarin }\end{array}$ & $\begin{array}{l}0.07-1.95 \mathrm{mg} / \mathrm{g} \text { d.w. }{ }^{4} \\
0.16-0.33 \mathrm{mg} / \mathrm{g} \text { d.w. }{ }^{2} \\
0.27-0.86 \mathrm{mg} / \mathrm{g} \text { d.w. }{ }^{2} \\
0.16 \mathrm{mg} / \mathrm{g} \text { d.w. }\end{array}$ & $\begin{array}{l}\text { Freeze drying } \\
\text { Freeze drying } \\
\text { Freeze drying } \\
\text { Hot-air drying }\left(45^{\circ} \mathrm{C}\right)\end{array}$ & {$[40,79,79,85]$} \\
\hline Nobiletin & $\begin{array}{l}\text { Orange } \\
\text { Mandarin } \\
\text { Satsuma mandarin } \\
\text { Calamondin }\end{array}$ & $\begin{array}{l}0.41-0.65 \mathrm{mg} / \mathrm{g} \mathrm{d.w} .^{2} \\
0.45-0.61 \mathrm{mg} / \mathrm{g} \text { d.w. } \\
0.31 \mathrm{mg} / \mathrm{g} \mathrm{d} . \mathrm{w} . \\
0.86-2.70 \mathrm{mg} / \mathrm{g} \mathrm{d.w} .\end{array}$ & $\begin{array}{l}\text { Freeze drying } \\
\text { Freeze drying } \\
\text { Hot-air drying }\left(45^{\circ} \mathrm{C}\right) \\
\text { Freeze drying }\end{array}$ & {$[79,79,85,40]$} \\
\hline $\begin{array}{l}\text { 1.:. dry weig } \\
\text { 1: Quantifi } \\
\text { 2: Quantifi } \\
\text { 3: Quantifi } \\
\text { 4: Quantifi }\end{array}$ & $\begin{array}{l}\text {.: fresh weight } \\
\text { by HPLC-Diode ar } \\
\text { by HPLC-Diode ar } \\
\text { by HPLC-Photodio } \\
\text { by HPLC-UV detec }\end{array}$ & $\begin{array}{l}\text { y detector (DAD) } \\
\text { y detector (DAD) and } \\
\text { e array (PDA) detector } \\
\text { or }\end{array}$ & C-MS & \\
\hline
\end{tabular}


Table 2. Phenolic acid contents of the peels of different citrus species.

\begin{tabular}{|c|c|c|c|c|}
\hline Phenolic acids & Type of material & Quantity & Drying technique applied & Refs \\
\hline \multicolumn{5}{|c|}{ Hydroxycinnamic acids } \\
\hline Ferulic acid & $\begin{array}{l}\text { Mandarin } \\
\text { Mandarin } \\
\text { Satsuma mandarin } \\
\text { Mandarin } \\
\text { Satsuma mandarin } \\
\text { Lemon } \\
\text { Orange } \\
\text { Orange } \\
\text { Grapefruit } \\
\text { Grapefruit }\end{array}$ & 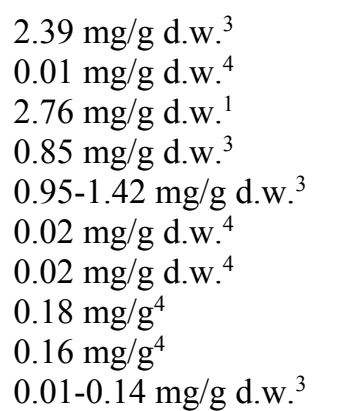 & $\begin{array}{l}\text { Sun drying } \\
\text { Freeze drying } \\
\text { Hot-air drying }\left(45^{\circ} \mathrm{C}\right) \\
\text { Sun drying } \\
\text { Hot-air drying }\left(40^{\circ} \mathrm{C}\right) \\
\text { Freeze drying } \\
\text { Freeze drying } \\
\text { N.M. } \\
\text { N.M. } \\
\text { Hot-air drying }\left(45^{\circ} \mathrm{C}\right)\end{array}$ & $\begin{array}{l}{[68,86,85,16,87,86,} \\
86,88,88,64]\end{array}$ \\
\hline $\begin{array}{l}p \text {-Coumaric } \\
\text { acid }\end{array}$ & $\begin{array}{l}\text { Mandarin } \\
\text { Mandarin } \\
\text { Satsuma mandarin } \\
\text { Mandarin } \\
\text { Satsuma mandarin } \\
\text { Lemon } \\
\text { Orange } \\
\text { Orange } \\
\text { Grapefruit } \\
\text { Grapefruit }\end{array}$ & $\begin{array}{l}0.83 \mathrm{mg} / \mathrm{g} \mathrm{d.w^{3 }} \\
0.05 \mathrm{mg} / \mathrm{g} \text { d.w. }{ }^{4} \\
0.30 \mathrm{mg} / \mathrm{g} \text { d.w. }{ }^{1} \\
0.35 \mathrm{mg} / \mathrm{g} \text { d.w. }{ }^{3} \\
0.02-0.18 \mathrm{mg} / \mathrm{g} \text { d.w. } \\
0.04 \mathrm{mg} / \mathrm{g} \mathrm{d.w.} .^{4} \\
0.01 \mathrm{mg} / \mathrm{g} \text { d.w. }{ }^{4} \\
0.08 \mathrm{mg} / \mathrm{g}^{4} \\
0.02 \mathrm{mg} / \mathrm{g}^{4} \\
0.01-0.07 \mathrm{mg} / \mathrm{g} \text { d.w. }{ }^{3}\end{array}$ & $\begin{array}{l}\text { Sun drying } \\
\text { Freeze drying } \\
\text { Hot-air drying }\left(45^{\circ} \mathrm{C}\right) \\
\text { Sun drying } \\
\text { Hot-air drying }\left(40^{\circ} \mathrm{C}\right) \\
\text { Freeze drying } \\
\text { Freeze drying } \\
\text { N.M. } \\
\text { N.M. } \\
\text { Hot-air drying }\left(45^{\circ} \mathrm{C}\right)\end{array}$ & $\begin{array}{l}{[68,86,85,16,87,86,} \\
86,88,88,64]\end{array}$ \\
\hline Caffeic acid & $\begin{array}{l}\text { Mandarin } \\
\text { Satsuma mandarin } \\
\text { Satsuma mandarin } \\
\text { Lemon } \\
\text { Orange } \\
\text { Orange } \\
\text { Grapefruit } \\
\text { Grapefruit }\end{array}$ & $\begin{array}{l}0.01 \mathrm{mg} / \mathrm{g} \mathrm{d} . \mathrm{w}^{4} \\
0.14 \mathrm{mg} / \mathrm{g} \mathrm{d} .{ }^{1} \\
0.04-0.06 \mathrm{mg} / \mathrm{g} \mathrm{d} . \mathrm{w}^{3}{ }^{3} \\
0.02 \mathrm{mg} / \mathrm{g} \mathrm{d.w} .{ }^{4} \\
0.02 \mathrm{mg} / \mathrm{g} \mathrm{d.w} .^{4} \\
0.01 \mathrm{mg} / \mathrm{g}^{4} \\
0.01 \mathrm{mg} / \mathrm{g}^{4} \\
0.001-0.01 \mathrm{mg} / \mathrm{g} \text { d.w. }{ }^{3}\end{array}$ & $\begin{array}{l}\text { Freeze drying } \\
\text { Hot-air drying }\left(45^{\circ} \mathrm{C}\right) \\
\text { Hot-air drying }\left(40^{\circ} \mathrm{C}\right) \\
\text { Freeze drying } \\
\text { Freeze drying } \\
\text { N.M. } \\
\text { N.M. } \\
\text { Hot-air drying }\left(45^{\circ} \mathrm{C}\right)\end{array}$ & $\begin{array}{l}{[86,85,87,86,86,88,} \\
88,64]\end{array}$ \\
\hline
\end{tabular}




\begin{tabular}{|c|c|c|c|c|}
\hline Sinapic acid & Mandarin & $0.02 \mathrm{mg} / \mathrm{g} \mathrm{d} . \mathrm{w} .^{4}$ & Freeze drying & {$[86,85,87,86,86,88$, } \\
\hline & Satsuma mandarin & $0.19 \mathrm{mg} / \mathrm{g} \mathrm{d.w}$. & Hot-air drying $\left(45^{\circ} \mathrm{C}\right)$ & $88,64]$ \\
\hline & Satsuma mandarin & $0.12-0.16 \mathrm{mg} / \mathrm{g}$ d.w. ${ }^{3}$ & Hot-air drying $\left(40^{\circ} \mathrm{C}\right)$ & \\
\hline & Lemon & $0.07 \mathrm{mg} / \mathrm{g} \mathrm{d} . \mathrm{w}^{4}$ & Freeze drying & \\
\hline & Orange & $0.01 \mathrm{mg} / \mathrm{g}$ d.w. ${ }^{4}$ & Freeze drying & \\
\hline & Orange & $0.10 \mathrm{mg} / \mathrm{g}^{4}$ & N.M. & \\
\hline & Grapefruit & $0.03 \mathrm{mg} / \mathrm{g}^{4}$ & N.M. & \\
\hline & Grapefruit & $0.001-0.05 \mathrm{mg} / \mathrm{g} \mathrm{d} . \mathrm{w} .^{3}$ & Hot-air drying $\left(45^{\circ} \mathrm{C}\right)$ & \\
\hline Chlorogenic & Grapefruit & $0.02-0.13 \mathrm{mg} / \mathrm{g} \mathrm{d} . \mathrm{w}^{3}$ & Hot-air drying $\left(45^{\circ} \mathrm{C}\right)$ & {$[64,86,86,86]$} \\
\hline acid & Lemon & $0.09 \mathrm{mg} / \mathrm{g} \mathrm{d.w}{ }^{4}$ & Freeze drying & \\
\hline & Orange & $0.02 \mathrm{mg} / \mathrm{g} \mathrm{d} . \mathrm{w}{ }^{4}$ & Freeze drying & \\
\hline & Mandarin & $0.04 \mathrm{mg} / \mathrm{g} \mathrm{d.w}{ }^{4}$ & Freeze drying & \\
\hline Hydroxybenzoic & acids & & & \\
\hline Vanillic acid & Mandarin & $0.32 \mathrm{mg} / \mathrm{g} \mathrm{d} . \mathrm{w} .^{3}$ & Sun drying & {$[68,85,16,87,64]$} \\
\hline & Satsuma mandarin & $0.05 \mathrm{mg} / \mathrm{g}$ d.w. ${ }^{1}$ & Hot-air drying $\left(45^{\circ} \mathrm{C}\right)$ & \\
\hline & Mandarin & $0.39 \mathrm{mg} / \mathrm{g} \mathrm{d} . \mathrm{w}^{3}$ & Sun drying & \\
\hline & Satsuma mandarin & $0.03 \mathrm{mg} / \mathrm{g} \mathrm{d} . \mathrm{w} .^{3}$ & Hot-air drying $\left(40^{\circ} \mathrm{C}\right)$ & \\
\hline & Grapefruit & $0.001-0.16 \mathrm{mg} / \mathrm{g} \mathrm{d} . \mathrm{w} .^{3}$ & Hot-air drying $\left(45^{\circ} \mathrm{C}\right)$ & \\
\hline$p-$ & Mandarin & $0.07 \mathrm{mg} / \mathrm{g} \mathrm{d} . \mathrm{w}^{3}$ & Sun drying & {$[68,85,16,87,64]$} \\
\hline Hydroxybenzoic & Satsuma mandarin & $0.06 \mathrm{mg} / \mathrm{g} \mathrm{d}$.w. ${ }^{1}$ & Hot-air drying $\left(45^{\circ} \mathrm{C}\right)$ & \\
\hline acid & Mandarin & $0.30 \mathrm{mg} / \mathrm{g} \mathrm{d} . \mathrm{w}^{3}$ & Sun drying & \\
\hline & Satsuma mandarin & $0.03 \mathrm{mg} / \mathrm{g} \mathrm{d} . \mathrm{w}^{3}$ & Hot-air drying $\left(40^{\circ} \mathrm{C}\right)$ & \\
\hline & Grapefruit & $0.002-0.01 \mathrm{mg} / \mathrm{g} \mathrm{d} . \mathrm{w} .^{3}$ & Hot-air drying $\left(45^{\circ} \mathrm{C}\right)$ & \\
\hline Gallic acid & Mandarin & $0.18 \mathrm{mg} / \mathrm{g} \mathrm{d} . \mathrm{w} .^{3}$ & Sun drying & {$[68,16]$} \\
\hline & Mandarin & $0.18 \mathrm{mg} / \mathrm{g} \mathrm{d.w}{ }^{3}$ & Sun drying & \\
\hline w.: dry weight.; & M.: not mentioned & & & \\
\hline 1: Quantificatio & by HPLC-Diode arr & letector (DAD) & & \\
\hline 2: Quantificatio & by HPLC-Diode arr & detector (DAD) and HF & -MS & \\
\hline 3: Quantificatio & by HPLC-Photodiod & rray (PDA) detector & & \\
\hline
\end{tabular}


Table 3. Merits and demerits of the different drying processes that have been applied on citrus by-products.

\begin{tabular}{|c|c|c|c|}
\hline Drying technique & Merits & Demerits & Refs \\
\hline Freeze drying & $\begin{array}{l}\text { - The change of the citrus by-product color is } \\
\text { negligible. } \\
\text { - Promotes the storability of the product by } \\
\text { minimizing pathogen and enzyme activity. } \\
\text { - Prevention of the polyphenol enzymatic } \\
\text { degradation due to oxygen absence. } \\
\text { - Prevention of the degradation of the heat } \\
\text { sensitive polyphenols. }\end{array}$ & $\begin{array}{l}\text { - Higher energy consumption and cost } \\
\text { requirements compared with the hot-air } \\
\text { drying, vacuum drying, microwave } \\
\text { drying, high-speed drying and infrared } \\
\text { drying. } \\
\text { It requires longer drying times than hot- } \\
\text { air drying, vacuum drying, microwave } \\
\text { drying, high-speed drying and infrared } \\
\text { drying. } \\
\text { It does not facilitate the liberation of } \\
\text { bound polyphenols. }\end{array}$ & {$[10,18,19,45]$} \\
\hline Hot-air drying & $\begin{array}{l}\text { - Less energy consumption and cost requirements } \\
\text { than freeze-drying. } \\
\text { - It requires shorter drying times than freeze } \\
\text { drying and sun drying. } \\
\text { - High temperatures may promote the liberation of } \\
\text { some bound polyphenols. }\end{array}$ & $\begin{array}{l}\text { - Brown color is developed as the } \\
\text { temperature increases. } \\
\text { A degradation of the heat and oxygen } \\
\text { sensitive polyphenols may occur. }\end{array}$ & $\begin{array}{l}{[9,10,37,39} \\
\quad 43,44,46]\end{array}$ \\
\hline Vacuum drying & $\begin{array}{l}\text { Less energy consumption requirements than } \\
\text { freeze drying and hot-air drying. } \\
\text { - Lower processing temperatures compared to } \\
\text { hot-air drying. } \\
\text { - High temperatures may facilitate the liberation } \\
\text { of some bound polyphenols. } \\
\text { - Prevention of the polyphenol enzymatic } \\
\text { degradation due to oxygen absence. }\end{array}$ & $\begin{array}{l}\text { - Brown color is developed as the } \\
\text { temperature increases. } \\
\text { - A degradation of the heat sensitive } \\
\text { polyphenols may occur. }\end{array}$ & {$[10,55,56,89]$} \\
\hline Sun drying & $\begin{array}{l}\text { Less energy consumption and cost requirements } \\
\text { compared with the other drying techniques. }\end{array}$ & $\begin{array}{l}\text { * It depends on environmental conditions } \\
\text { (humidity, temperature, air velocity, } \\
\text { and solar intensity). } \\
\text { It requires longer drying times than } \\
\text { other drying techniques, including } \\
\text { freeze drying. } \\
\text { A polyphenol enzymatic degradation } \\
\text { may occur due to the presence of } \\
\text { oxygen. }\end{array}$ & {$[9,34,68]$} \\
\hline
\end{tabular}


* Microbial contamination of the dried material may occur.

Microwave drying

High-speed drying

Infrared drying
* Less energy consumption requirements than freeze drying, hot-air drying, vacuum drying, sun drying, infrared drying, and high-speed drying.

* It requires shorter drying times compared to freeze drying, hot-air drying, vacuum drying, infrared drying, and high-speed drying.

* The liberation of the bound phenolics can be achieved.

* It requires shorter drying times than freeze drying, hot-air drying, vacuum drying, sun drying, and infrared drying

* It facilitates high retention of polyphenols in the dried material.

- It requires shorter drying time than freeze drying and sun drying.
- A polyphenol enzymatic degradation may occur due to the presence of oxygen.

* A degradation of the heat sensitive polyphenols may occur.

* Brown color is developed as the power and processing time increase.

- The cost of equipment could be higher than other drying techniques, such as hot-air drying, vacuum drying, or sun drying.

It results in lower retention of total polyphenols compared to freeze drying.
$[9,18,19$,

$42,60,89$,

90]

$[9,18,19$,

$60,89,90]$

$[9,18]$ 
Table 4. Drying techniques applied on citrus by-products.

\section{Drying treatments}

\begin{tabular}{|c|c|c|c|}
\hline Citrus species & Drying procedures & Comments & Refs \\
\hline \multirow{3}{*}{$\begin{array}{l}\text { Naranjita (Citrus mitis B.) } \\
\text { by-products }\end{array}$} & \multirow{3}{*}{$\begin{array}{l}\text { Hot-air drying (50- } \\
\left.84^{\circ} \mathrm{C}\right)\end{array}$} & * The drying process increased both total phenolic content and antioxidant capacity. & \multirow[t]{3}{*}{ [46] } \\
\hline & & Higher retention of TPC was observed in the dried by-products compared to the fresh ones. & \\
\hline & & $\begin{array}{l}* \text { The highest content of TPC can be obtained with the combination of high temperatures }(>74 \\
\left.{ }^{\circ} \mathrm{C}\right) \text { and low air velocity }(<0.6 \mathrm{~m} / \mathrm{s}) \text {. }\end{array}$ & \\
\hline
\end{tabular}

Lemon (Citrus limon) byproducts

Yuzu (Citrus junos Sieb ex Tanaka) peels

Lemon (Citrus limon v. lunari) peels

Lemon (Citrus limon) fruits

Lemon (Citrus limon cv. lunari) peels
* Freeze drying

* Hot-air drying (70, 90 and $110^{\circ} \mathrm{C}$ )

* Vacuum drying $\left(70,90\right.$ and $\left.110^{\circ} \mathrm{C}\right)$

- Microwave drying

- Hot-air drying (50 ${ }^{\circ} \mathrm{C}$ )

- Freeze drying

* Air drying $\left(25^{\circ} \mathrm{C}\right)$

- Combined osmotic hot-air drying dehydration

* Hot-air drying (45 ${ }^{\circ} \mathrm{C}$ )

* Freeze drying

- Hot-air drying (40, 50 and $60^{\circ} \mathrm{C}$ )
* The TPC and antioxidant capacity were higher in the lemon by-products dried by hot-air or under vacuum than those dried by freeze drying.

* The highest recovery of flavonoids was recorded in the by-products dried under vacuum at 70 and $90{ }^{\circ} \mathrm{C}$.

* By-products dried under vacuum at $70{ }^{\circ} \mathrm{C}$ had the highest rutin and $p$-coumaric acid content. The highest recovery of gallic acid was recorded in the by-products dried by hot-air at $110^{\circ} \mathrm{C}$.

* All the drying methods resulted in higher values of TPC, flavonoid content and antioxidant capacity compared to those obtained from the fresh samples.

* Hot-air, microwave, and air drying resulted in the reduction of the TPC, flavonoid content and antioxidant capacity compared to freeze drying.

* Peels dried by hot-air drying had the same TPC, flavonoid content and antioxidant capacity with those dried by microwave drying.

* Freeze drying resulted in the highest retention of TPC, flavonoid content, and antioxidants.

* Osmotic dehydration process had protective effect against TPC loss during hot-air drying.

* Significant loss of TPC (70-80\%) was recorded during osmotic dehydration.

* Sample dehydration provided extracts with higher amounts of flavonoids than fresh samples.

* The flavonol content was higher in the extracts obtained from the hot-air dried samples compared to those dried by freeze drying.

* The flavanone and flavone contents were higher in the extracts obtained from the freeze dried samples compared to those dried by hot-air drying.

* Drying temperature had a significant effect on the TPC degradation rates. 
* Hot-air drying led to a significant reduction in the TPC and flavonoid content.

* A first-order equation described the degradation of TPC and flavonoid content.

Oranges (Citrus sinensis) peels

Immature kumquat (Citrus japonica var. margarita) fruits

Different citrus species

Immature calamondin (Citrus mitis Blanco) peels

Orange (Citrus sinensis. v. thompson); lemon (Citrus

limon. v. lunari); mandarin (Citrus reticulata. v. tangerine) peels

Orange

(Citrus Sinensis) peels
* Hot-air drying (40, 60 and $80^{\circ} \mathrm{C}$ )

* Freeze drying

- Hot-air drying $(110,130$ and 150 ${ }^{\circ} \mathrm{C}$ ) followed by freeze drying

* Sun drying

* Hot-air drying (60 $\left.{ }^{\circ} \mathrm{C}\right)$

* Freeze drying

* Hot-air drying $(70$, 85,100 and 150 ${ }^{\circ} \mathrm{C}$ ) followed by freeze drying

- Microwave drying (100-600W)

- Microwave drying

$(100-850 \mathrm{~W})$
* The highest content of major individual flavonoids and antioxidant activity of orange pee achieved at $80^{\circ} \mathrm{C}$

* A rapid degradation of total and individual compounds occurred during the first hour of drying.

* When fruits were dried at 110 and $130{ }^{\circ} \mathrm{C}$ for $0.5 \mathrm{~h}$, the TPC, antioxidant activity, and flavonoid content increased.

* All of the flavonoids dramatically decreased after drying at $150{ }^{\circ} \mathrm{C}$ for $1.5 \mathrm{~h}$.

* The TPC and antioxidant capacity were higher in hot-air dried samples compared to the lyophilized.

* Hot-air drying is a good way to retain flavonoids in the dried material.

* Freeze drying resulted in extracts with the highest phenolic acid content and antioxidant activity among the four citrus species.

* The TPC of all citrus fruits was reduced after hot-air drying at $60{ }^{\circ} \mathrm{C}$.

* Both hot-air and sun drying caused some loss of phenolic acids.

* The peels dried at $150{ }^{\circ} \mathrm{C}$ for $1.5 \mathrm{~h}$ had the highest TPC and flavonoid content compared to the other treatments and fresh materials.

* The heating enhanced the release of some phenolic compounds i.e., naringin, tangeretin, ferulic acid, $p$-coumaric acid, and gallic acid.

* Some phenolic compounds, such as 3',5'-di-C- $\beta$-glucopyranosylphloretin (DGPP), hesperidin and caffeic acid, were degraded during heating.

* Microwave power significantly affected the retention of TPC in the difference citrus species.

* As the microwave power increased from 300 to $600 \mathrm{~W}$ the TPC of the microwave dried mandarin and orange peels increased.

* Microwave power higher than 450W resulted in the decrease of TPC of the microwave dried lemon peels.

* Microwave power significantly affected the retention of TPC on the dried orange peels.

* Drying power of 450W was found to result in high amount of TPC retention. 
Orange

(Citrus sinensis L. Osbeck)

peels

- Hot-air drying $(50$,

$60,70,80,90$ and

$100{ }^{\circ} \mathrm{C}$ ),

* Freeze drying

\section{Orange}

* Infrared drying

(Citrus Sinensis) peels

Citrus by-products

Citrus by-products

* Far-infrared drying

* High-speed drying
* Lower TPC and flavonoid contents were recorder in the peels dried at lower temperatures (50 and $\left.60^{\circ} \mathrm{C}\right)$, than to those dried at higher $\left(70,80,90\right.$ and $\left.100{ }^{\circ} \mathrm{C}\right)$.

- Peels dried at temperatures higher than $70^{\circ} \mathrm{C}$ had higher TPC compared to those dried by freeze drying.

* Caffeic acid, p-coumaric acid, naringin, neohesperidin, kaempferol, and rutin contents were higher in the peels dried at $100{ }^{\circ} \mathrm{C}$, compared to those dried at lower temperatures or freeze dried.

* The TPC was higher in the peels dried at higher infrared drying temperatures.

* The infrared drying peels retained lower TPC compared to fresh.

* The TPC of the extracts obtained from the far-infrared dried by-products was lower than those dried by freeze drying.

* Far-infrared drying is effective for retaining specific phenolic compounds in citrus by-products.

* Freeze drying

* High speed dried extracts showed high amount of polymethoxylated flavones (heptamethoxyflavone and nobiletin) and flavanones (hesperidin and narirutin).

* The TPC and flavonoid content of the extracts obtained from the high-speed dried peels were close to those obtained by the freeze dried ones. 
Table 5. Post-drying treatments applied on dried citrus for liberating phenolic compounds and enhancing the polyphenol content of the extracts.

\section{After drying treatments}

\begin{tabular}{ll}
\hline Citrus species & Technique \\
\hline Lemon by-products & The freeze dried lemon by- \\
& $\begin{array}{l}\text { products were treated with } \\
\text { different ultraviolet C }\end{array}$
\end{tabular}

(UV-C) irradiations.

Lemon by-products

Mandarin byproducts

Citrus unshiu byproducts

Huyou peels

products were treated different microwave powers for different intervals.

* The sun dried by-products were treated with different microwave powers for

* The freeze dried peels were treated with electronbeam irradiation.

* The hot-air dried peels different intervals. were heated in an electric oven at different temperatures for different intervals.

\section{Comments}

* UV-C irradiation of $19 \mathrm{~kJ} / \mathrm{m}^{2}$ resulted in extracts with higher TPC than the control, while UV-C irradiation of $180 \mathrm{~kJ} / \mathrm{m}^{2}$ resulted in extracts with higher total flavonoid and proanthocyanidin contents than the control.

* UV-C irradiation more than $4 \mathrm{~kJ} / \mathrm{m}^{2}$ resulted in the decrease of the antioxidant capacity.

* Appropriate microwave treatment resulted in the increase of the TPC, total flavonoids, proanthocyanidins and total antioxidant capacity of the extracts.

\section{Refs}

[25]

* Appropriate microwave treatment could liberate and activate the bound phenolic compounds of the mandarin by-products.

* Appropriate microwave treatment could enhance the antioxidant capacity of citrus by-products.

* The TPC and radical scavenging activity of the freeze dried by-product powder treated at $37.9 \mathrm{kGy}$, significantly increased compared to the nonirradiated control.

* Heat treatment resulted in the increase of the free phenolic acid content, and the decrease of ester, glycoside, and ester-bound phenolic acids.

Heat treatment resulted in the decreased of the flavanone glycosides.

* After heat treatment the antioxidant capacity of the extracts increased. 
Citrus unshiu peels

* The dried peels were heated in an electric muffle furnace at different temperatures for different intervals.
- The extracts of the dried citrus peels treated at $150{ }^{\circ} \mathrm{C}$ had higher TPC and radical scavenging activity compared to those obtained from the nonheated control.

Several low molecular weight phenolic compounds such as ferulic acid, 5-hydroxyvaleric acid, 2,3-diacetyl-1-phenylnaphthalene, vanillic acid etc. were newly formed in the peels treated at $150^{\circ} \mathrm{C}$. 


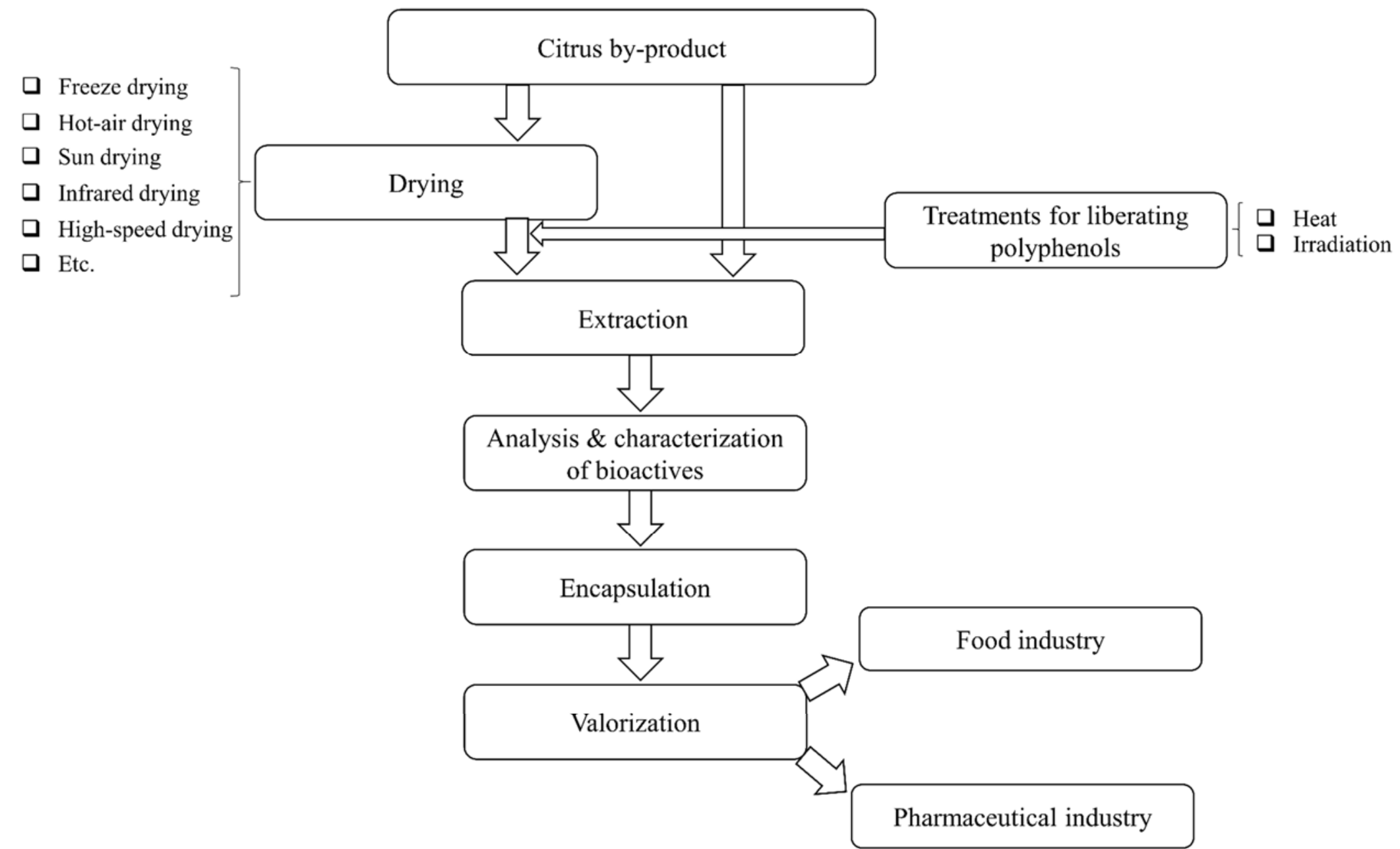

Fig. 1. Steps for the valorization of polyphenols from citrus wastes. 


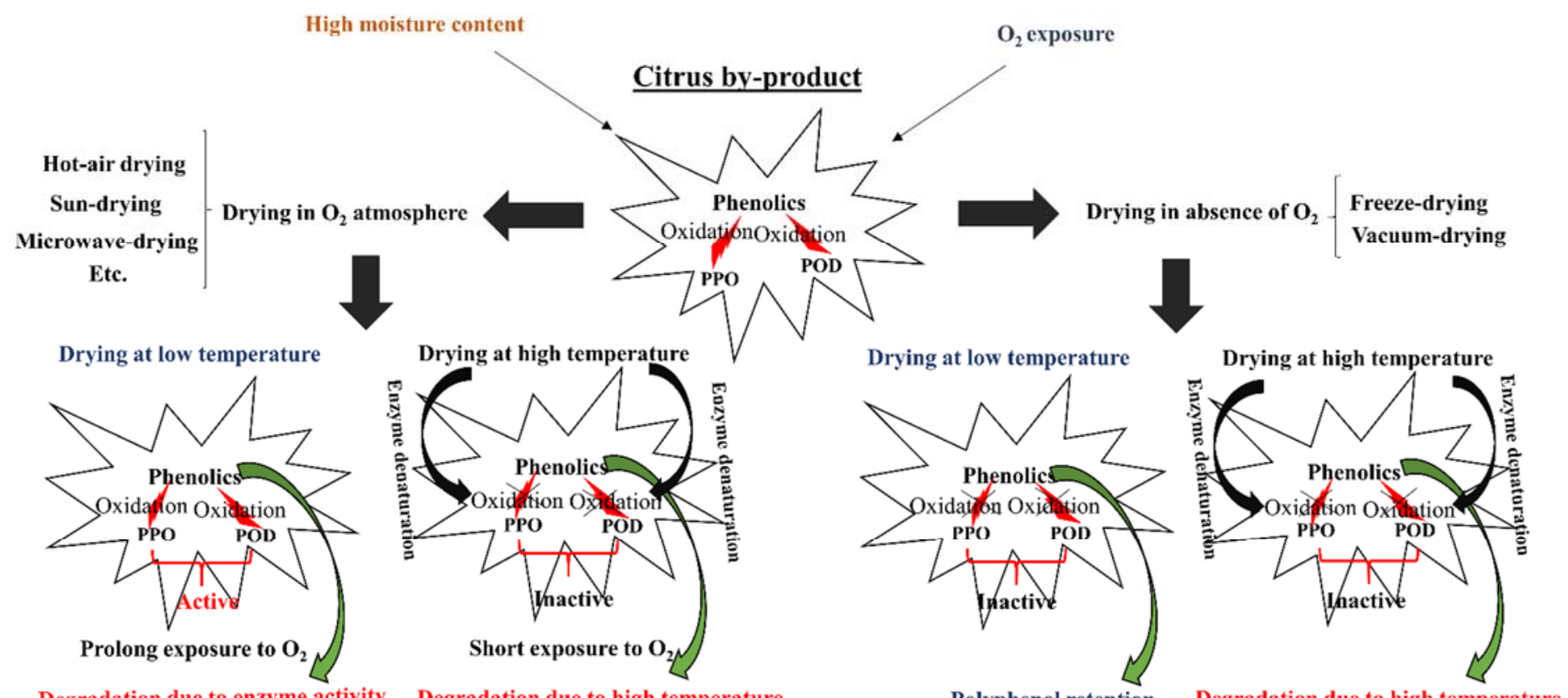

Degradation due to enzyme activity Degradation due to high temperature

Polyphenol retention Degradation due to high temperature

Fig. 2. Effect of different drying conditions on the enzymatic degradation of polyphenols. 


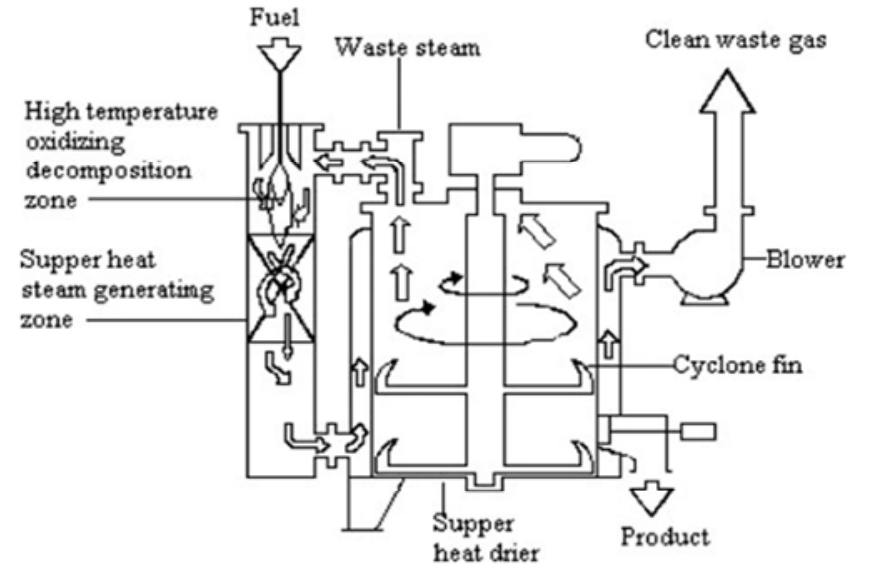

Fig. 3. Flow diagram of high speed drier (Model: Okadora Korea). Reprinted from J. Food Eng., 92, Senevirathne, M.; Jeon, Y.J.; Ha, J.H.; Kim, S.H., Effective drying of citrus by-product by high speed drying: A novel drying technique and their antioxidant activity, 2009, 157-163, Copyright (2017), with permission from Elsevier. 

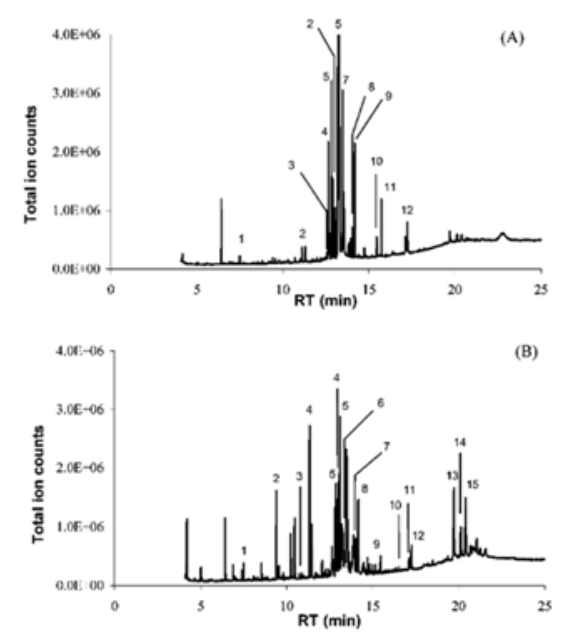

Fig. 4. Typical gas chromatography of $70 \%$ ethanol extracts from citrus peels nonheated (A) and heated (B) at $150{ }^{\circ} \mathrm{C}$ for $30 \mathrm{~min}$. Peaks in (A): 1 , bishydroxybutanedioic acid; 2, 2-azathianthrene; 3, 2-oxybenzoic acid; 4, $1 H$-indole-3-carboxaldehyde; 5, arabinofuranose; 6, $\alpha$-DL-arabinofuranoside; 7, $\beta$-L-arabinopyranose; 8, glucopyranose; 9, palmitic acid; 10, 2,4-bishydroxybenzaldehyde; 11, stearic acid. Peaks in (B): 1, bishydroxybutanedioic acid; 2, 2,3-diacetyl-1-phenylnaphthalene; 3, 1,2-ben-zenedicarboxylic acid ethyl ester; 4, 2-azathianthrene; 5, arabinofuranose; 6, $\beta$-D-galactofuranose; 7, $\beta$-L-arabinopyranose; 8 , glucopyranose; 9 , palmitic acid; 10 , ferulic acid; $11, p$-hydroxybenzaldoxime; 12 , stearic acid; 13, D-ribofuranose; 14, glucofuranoside; 15, $\beta$-D-galactofuranoside. Reprinted from J. Agric. Food Chem. with permission from Jeong, S.M.; Kim, S.Y.; Kim, D.R.; Jo, S.C.; Nam, K.C.; Ahn, D.U.; Lee, S.C. Effect of heat treatment on the antioxidant activity of extracts from citrus peels. 2004, 52, 3389-3393. Copyright (2017) American Chemical Society. 